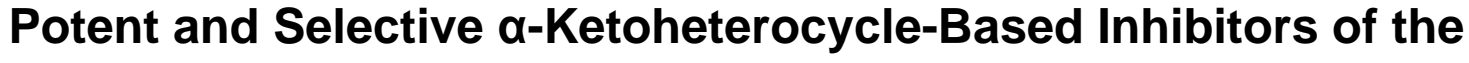 Anandamide and Oleamide Catabolizing Enzyme, Fatty Acid
}

\section{Amide Hydrolase}

\author{
F. Anthony Romero ${ }^{\dagger} \ddagger$, Wu Du ${ }^{\dagger, \ddagger}$, Inkyu Hwang ${ }^{\dagger, \ddagger}$, Thomas J. Rayl $\left.\right|^{\dagger, \ddagger}$, F. Scott Kimball ${ }^{\dagger, \ddagger}$ \\ Donmienne Leung $\S, \ddagger$, Heather S. Hoover $\S, \ddagger$, Richard L. Apodaca $\Psi$, J. Guy Breitenbucher $\Psi$, \\ Benjamin F. Cravatt $\$, \ddagger$, and Dale L. Boger ${ }^{\star}, \dagger, \neq$ \\ $\dagger$ Department of Chemistry, The Scripps Research Institute, 10550 North Torrey Pines Road, La Jolla, \\ California 92037
}

$\S$ Department of Cell Biology, The Scripps Research Institute, 10550 North Torrey Pines Road, La Jolla, California 92037

\$ The Skaggs Institute for Chemical Biology, The Scripps Research Institute, 10550 North Torrey Pines Road, La Jolla, California 92037

$\Psi$ Johnson \& Johnson Pharmaceutical Research and Development, L.L.C., 3210 Merryfield Row, San Diego, CA 92121

\begin{abstract}
A study of the structure-activity relationships (SAR) of $\mathbf{2 f}$ (OL-135), a potent inhibitor of fatty acid amide hydrolase (FAAH), is detailed targeting the 5-position of the oxazole. Examination of a series of substituted benzene derivatives (12-14) revealed that the optimal position for substitution was the meta-position with selected members approaching or exceeding the potency of $\mathbf{2 f}$. Concurrent with these studies, the effect of substitution on the pyridine ring of $\mathbf{2} \mathbf{f}$ was also examined. A series of small, non-aromatic C5-substituents was also explored and revealed that the $K_{\mathrm{i}}$ follows a well-defined correlation with the Hammett $\boldsymbol{\sigma}_{\mathrm{p}}$ constant $\left(\rho=3.01, \mathbf{R}^{2}=0.91\right)$ in which electron-withdrawing substituents enhance potency leading to inhibitors with $K_{\mathrm{i}}$ 's as low as $400 \mathrm{pM}(\mathbf{2 0 n})$. Proteomic-wide screening of the inhibitors revealed that most are exquisitely selective for FAAH over all other mammalian proteases reversing the 100 -fold preference of $20 \mathbf{a}(\mathrm{C} 5$ substituent $=\mathrm{H})$ for the enzyme TGH.
\end{abstract}

Fatty acid amides are an important new class of lipid signaling molecules that modulate a number of physiological processes. Two endogenous fatty acid amides, anandamide (1a) ${ }^{1}$ and oleamide (1b) ${ }^{2-4}$ have emerged as prototypical members of this class that serve as chemical messengers (Figure 1). Anandamide (1a), which was only discovered a little more than a decade ago and is the most recognizable member of the endogenous fatty acid ethanolamides, ${ }^{5}$ binds and activates both the central type-1 (CB1) and peripheral type-2 (CB2) cannabinoid receptors. Anandamide (1a), and members of the cannabinoid family, ${ }^{6}$ have been implicated in the modulation of nociception, ${ }^{7-9}$ feeding, ${ }^{10,11}$ emesis, anxiety, ${ }^{12}$ cell proliferation, 13,14 inflammation, ${ }^{15}$ memory 16 and neuroprotection after brain injury. ${ }^{17}$ Thus, the cannabinoids have clinical relevance for analgesia, anxiety, epilepsy, cachexia, cancer, and Alzheimer's disease as well as other neurodegenerative diseases. ${ }^{18-20}$

*CORRESPONDING AUTHOR: Dale L. Boger, Department of Chemistry, The Scripps Research Institute, 10550 North Torrey Pines Rd., La Jolla, CA 92037. Phone: 858-784-7522. Fax: 858-784-7550. E-mail: boger@ scripps.edu. 
Oleamide (1b) was found to accumulate in the cerebrospinal fluid of animals under conditions of sleep deprivation and to induce physiological sleep in a dose dependent manner where it reduced motility, shortened the sleep induction period, and lengthened the time spent in slow wave sleep 2 at the expense of wakening. ${ }^{2,4}$ In a structurally specific manner, it was found to modulate serotonergic systems ${ }^{21-23}$ and GABAergic transmission, 24,25 block glial gap junction cell-cell communication, ${ }^{26,27}$ decrease body temperature and locomotor activity, 28 and exhibit the characteristic in vivo analgesic and cannabinoid behavorial effects of anandamide, ${ }^{21,29}$ albeit without direct cannabinoid receptor activation. It has been suggested that the cannabinoid behavorial effects of oleamide (1b) may be mediated through an as yet unknown distinct pharmacological target. ${ }^{24}$ Because oleamide (1b) may play a critical role in sleep, it may provide an exciting therapeutic potential for the development of sleep aids that induce physiological sleep lacking the side effects of the sedative-hypnotics (e.g., benzodiazepene class), which include rebound insomnia, anterograde amnesia and suicide abuse potential.

The pharmacological action of anandamide (1a) and oleamide (1) $\mathbf{1})$ is terminated by the enzyme fatty acid amide hydrolase (FAAH, Figure 1) ${ }^{30-33}$ Fatty acid amide hydrolase is an integral membrane protein that degrades the fatty acid amide family of endogenous signaling lipids. 34,35 Its central nervous system distribution indicates that it degrades neuromodulating fatty acid amides at their sites of action and is intimately involved in their regulation. ${ }^{36}$ Fatty acid amide hydrolase is currently the only characterized mammalian enzyme that is in the amidase signature family bearing an unusual catalytic Ser-Ser-Lys triad. ${ }^{30,33,37-39}$ Recently, the crystal structure of FAAH cocrystallized with an irreversibly-bound arachidonyl fluorophosphonate confirmed its unusual catalytic triad and provided structural details of this enzyme. ${ }^{30}$ Studies with FAAH knockout mice have not only shown that this enzyme is a key regulator of fatty acid amide signaling in vivo, but that there are also significant augmented behavioral responses (e.g., increased analgesia, hypomotility, catalepsy) to administered anandamide (1a) and oleamide (1b) resulting from increased brain levels of the fatty acid amides that correlated with a CB1-dependent analgesic phenotype. ${ }^{40-43}$ As such, FAAH has emerged as an interesting new therapeutic target for a range of clinical disorders. ${ }^{6,44}$

Due to the potential therapeutic relevance of inhibiting FAAH, there has been increasing interest in developing potent and selective inhibitors of this enzyme (Figure 2). ${ }^{12,45-60}$ These include the discovery that the endogenous sleep-inducing molecule 2-octyl $\alpha$ -

bromoacetoacetate (2a) is an effective FAAH inhibitor,, 55 a series of reversible inhibitors bearing an electrophilic ketone ${ }^{46,54,56,61}$ (e.g., trifluoromethyl ketone $2 \mathbf{b}$ ) that have not proven selective for FAAH over other mammalian serine hydrolases ${ }^{62}$ and a set of irreversible inhibitors $48-50,52,53$ (e.g., fluorophosphonate $\mathbf{2 c}$ and sulfonyl fluorides). Recently, two classes of compounds have been disclosed that provide significant advances in the development of an inhibitor with therapeutic potential. One class is the aryl carbamates (e.g., 2d) that acylate an active site catalytic serine and which were shown to exhibit anxiolytic actvitiy and induce analgesia. $12,57-59,63,64$ However, the selectivity of such aryl carbamate inhibitors is low and recent studies show that either no or minimal selectivity is achieved (e.g., other targets of $\mathbf{2 d}$ are carboxylesterase 6 and triacylglyceride hydrolase). ${ }^{64-66}$ A second class is the $\alpha$ ketoheterocycle-based inhibitors of which some are extraordinarily potent (e.g., $\mathbf{2 e}$ and $\mathbf{2 f}$ ). $45,47,51,62,67$ These competitive inhibitors bind to FAAH via reversible hemiketal formation with an active site serine and are not only potent and extraordinarily selective for FAAH versus other mammalian serine hydrolases, ${ }^{45,62}$ but many are efficacious in vivo and promote analgesia. 66,68

From these latter studies, $\mathbf{2 f}$ has emerged as an advanced lead. ${ }^{45,51,62,66-68}$ It has been shown that $2 \mathrm{f}$ is a potent FAAH inhibitor $\left(K_{\mathrm{i}}=4.7 \mathrm{nM}\right)$ that induces analgesia by raising endogenous anandamide levels, ${ }^{66}$ is more than 300 -fold selective for FAAH over any other serine 
hydrolase, ${ }^{45}$ lacks significant offsite target activity when surveyed against a full panel of receptors and enzymes (Cerep assay profiling), and does not significantly inhibit the common P450 metabolism enzymes (3A4, 2C9, 2D6) or the human ether-a-go-go related gene (hERG). As part of a continuing program in developing FAAH inhibitors, it was of interest to more fully explore the structure-activity relationships (SAR) of $\mathbf{2 f}$ targeting the 5-position of the central oxazole ring (e.g., various aryl and non-aromatic substituents). Herein we report the synthesis and evaluation of this more extensive series of 5-substituted 7-phenyl-1-(oxazol-2-yl)heptan-1ones along with the results of proteome-wide selectivity screening of candidate inhibitors. ${ }^{69}$

\section{Chemistry}

Key to the divergent synthesis of the inhibitors was the preparation of the intermediate $4^{45}$ from which all the requisite compounds could be synthesized. Intermediate 4 was obtained by Vedejs oxazole metalation, ${ }^{70}$ condensation with 7-phenylheptanal and TBS protection of the resulting alcohol. Selective $\mathrm{C} 5$-oxazole lithiation ${ }^{71}$ of $\mathbf{4}$ followed by treatment with $\mathrm{Bu}_{3} \mathrm{SnCl}$ afforded stannane $\mathbf{5}$. Stille coupling 72 of stannane $\mathbf{5}$ with a systematic series of aryl halides produced 6-11, which could be readily converted to the corresponding 5-aryl substituted 7phenyl-1-(oxazol-2-yl)heptan-1-ones 12-17 via TBS deprotection and oxidation of the liberated alcohol with Dess-Martin periodinane. ${ }^{73}$

The synthesis of the candidate inhibitors that bear a non-aromatic C5-oxazole substituent is summarized in Scheme 2. After selective C5-oxazole lithiation, 4 was treated with a range of electrophiles $\left(\mathrm{CO}_{2}(\mathrm{~g}), \mathrm{CF}_{3} \mathrm{CON}\left(\mathrm{CH}_{3}\right)_{2}, \mathrm{CH}_{3} \mathrm{CON}\left(\mathrm{CH}_{3}\right)_{2}, \mathrm{DMF}, \mathrm{I}_{2}, \mathrm{Br}_{2}, \mathrm{~N}\right.$ -

chlorosuccinimide, $N$-fluorobenzenesulfonimide, $\mathrm{CH}_{3} \mathrm{I}$, dimethyldisulfide) to give $\mathbf{1 9 b}, \mathbf{1 9 g}$ i, 19o and 19q-u many of which served as precursors to additional candidate inhibitors bearing further modified C5-substituents. Carboxylic acid 20b was directly converted to a series of amides (20e, 20f, $20 \mathbf{j}-\mathbf{m} ; \mathrm{RNH}_{2}$ or $\mathrm{R}_{2} \mathrm{NH}, \mathrm{EDCI}$ and HOAt) as well as to its corresponding methyl ester 20c by treatment with $\mathrm{TMSCHN}_{2}$. The ester $20 \mathrm{c}$ was converted to the carboxamide 20d by treatment with methanolic ammonia. Carboxamide 20d was dehydrated with TFAA and pyridine to provide nitrile $\mathbf{2 0 n}$, which in turn was converted to the tetrazole $\mathbf{1 8 f}$ upon treatment with $\mathrm{NaN}_{3}$. Using a method developed by Chen et al., iodide $19 \mathbf{q}$ was transformed to $19 \mathrm{p}\left(\mathrm{FSO}_{2} \mathrm{CF}_{2} \mathrm{CO}_{2} \mathrm{CH}_{3}, \mathrm{CuI}\right)$ bearing a $\mathrm{C} 5$ trifluoromethyl substituent. ${ }^{74,75}$ The $O$-methyl pyrimidine derivatives $(\mathbf{1 8 d}, \mathbf{1 8 e})$ were treated with $\mathrm{TMSCl}$ and $\mathrm{NaI}$ to yield the uracil analogues $(\mathbf{2 0 v}, \mathbf{2 0 w})$. In each case, deprotection of the TBS ether followed by Dess-Martin periodinane oxidation of the liberated alcohol yielded the corresponding $\alpha$-ketoheterocycles.

\section{Enzyme Assay}

Enzyme assays were performed at $20-23{ }^{\circ} \mathrm{C}$ with purified recombinant rat $\mathrm{FAAH}$ expressed in $E$. coli ${ }^{76}$ (unless indicated otherwise) or with solubilized COS-7 membrane extracts from cells transiently transfected with human FAAH cDNA ${ }^{32}$ (where specifically indicated) in a buffer of $125 \mathrm{mM}$ Tris/ $1 \mathrm{mM}$ EDTA/0.2\% glycerol/0.02\% Triton X-100/0.4 mM Hepes, $\mathrm{pH}$ 9.0 buffer. ${ }^{55}$ The initial rates of hydrolysis $(\leq 10-20 \%$ reaction) were monitored using enzyme concentrations (typically $2 \mathrm{nM}$ ) at least two times below the measured $K_{\mathrm{i}}$ by following the breakdown of ${ }^{14} \mathrm{C}$-oleamide and $K_{\mathrm{i}}$ 's (standard deviations provided in Supporting Information Tables) established as described (Dixon plot). ${ }^{47}$ Lineweaver-Burk analysis previously established reversible, competitive inhibition for $\mathbf{2} \mathbf{f}$ and related compounds. ${ }^{45}$

\section{Results and Discussion}

\section{Aryl Substitution}

We previously disclosed a small set of 5-aryl substituted 7-phenyl-1-(oxazol-2-yl)heptan-1ones 45 and this study defined a smooth increase in inhibitory potency as the hydrogen-bonding 
capability of the 5-aryl substituent increased ( $2 \mathbf{h}$ to $\mathbf{2 g}$ to $\mathbf{2 f}$, Figure 3). Complete removal of the pyridine nitrogen of $\mathbf{2} \mathbf{f}$, providing compound $\mathbf{2 i}$, resulted in a significant loss of FAAH inhibitory potency $\left(K_{\mathrm{i}}=80 \mathrm{nM}, 140 \mathrm{nM}\right.$ reported in ref. $\left.{ }^{45}\right)$. This loss of inhibitory potency proved consistent with a loss in binding affinity due to a hydrogen-bond interaction. Monte Carlo simulations of $\mathbf{2} \mathbf{f}$ suggested that the pyridine nitrogen of $\mathbf{2} \mathbf{f}$ is involved in a direct hydrogen-bond to the hydroxyl of Thr236 and the protonated nitrogen of Lys142. ${ }^{45,77}$ As depicted in the modeling studies and as evidenced by the tolerated variance in the positioning of such pyridyl hydrogen-bond acceptors in a series of FAAH inhibitors, ${ }^{45}$ the interaction is between the conformationally mobile catalytic residues at the active site of the enzyme and is adaptable to the positioning of the hydrogen-bond as well as the residue (Ser217 and Lys142) involved. To further explore such interactions, a systematic series of benzene derivatives bearing substituents on the 2-, 3- and 4-positions was examined (Figure 4). Several important trends emerged from the examination of this series. Substitution at the 2-position (12 series) reduced inhibitory potency relative to the unsubstituted phenyl derivative $2 \mathbf{i}\left(\mathrm{R}=\mathrm{H}, K_{\mathrm{i}}=80\right.$ $\mathrm{nM}$ ), whereas substitution at the 3- (13 series) or 4-positions ( $\mathbf{1 4}$ series) moderately (up to 8fold for 4-substitution) or significantly (up to 40-fold for 3-substitution) enhanced the inhibitory potency. Without exception, the rank order FAAH inhibitory potency for each substituent is 3 -substitution > 4-substitution > 2 -substitution. It is likely that the 2 -substituents disfavor the near coplanar arrangement of the phenyl and oxazole rings observed in modeling studies 45,77 leading to the lower inhibitory potencies for this series versus $2 \mathbf{i}(R=H)$ itself. The exceptions to this generalization are small $(\mathbf{1 2 e}, \mathrm{R}=\mathrm{F} ; \mathbf{1 2 k}, \mathrm{R}=\mathrm{CN})$ electron-withdrawing $\left(\mathbf{1 2 c}, \mathrm{R}=\mathrm{CO}_{2} \mathrm{CH}_{3}\right.$ ) substituents that approach or match the activity of $\mathbf{2 i}$.

The 3- and 4-positions exhibit similar substituent trends, but with the 3-substituent providing inhibitors as much as 10-fold more potent than the corresponding 4-substituent (typically 2 to 3 -fold). Although the generalizations are not fully defined with this set of substituents, the increases in inhibitory potency relative to $\mathbf{2} \mathbf{i}$ were greatest with electron-withdrawing versus electron-donating substituents (e.g., $\mathrm{OH}, \mathrm{OCH}_{3}, \mathrm{NH}_{2}$ ) and appear to benefit further if the electron-withdrawing substituent embodies both hydrogen-bond acceptor and donor capabilities. It is possible that the electronic character of the substituent may be responsible for or contributes to the changes in $K_{\mathrm{i}}$ value especially for the 4-substituents. Here, the electrondonating substituents $\left(\mathrm{NH}_{2}, \mathrm{OCH}_{3}, \mathrm{OH}\right)$ provided inhibitors less active than the parent phenyl derivative 2i, whereas electron-withdrawing substituents enhanced the activity. However, the fact that the substituent effects do not smoothly follow rank order trends and that the most potent series constitute the meta (not para or ortho) substituents suggests that the electronic effect of the substituent is not the only source of the modulated binding affinities. Notably, several of the 3 -substituted derivatives (13 series) approach or match the potency of $\mathbf{2} \mathbf{f}\left(K_{\mathrm{i}}=\right.$ $4.7 \mathrm{nM}$ ), which benefits from the presence of the pyridyl group hydrogen-bond acceptor (20fold increase over phenyl derivative $2 \mathbf{i}$ ), without the deliberate use of a weakly basic heterocyclic nitrogen as a hydrogen-bond acceptor. ${ }^{45}$ The carboxylic acid of $\mathbf{1 3 d}$, carboxamide of $\mathbf{1 3 i}$ and primary sulfonamide of $\mathbf{1 3 h}$ appear to be in an optimal position in the active site to benefit from stabilizing binding interactions that match the effect of the pyridine nitrogen of 2f. Notably, 13d and $\mathbf{1 3 i}$ have FAAH inhibitory potencies indistinguishable from $\mathbf{2 f}$, whereas $\mathbf{1 3 h}$ is twice as potent as $\mathbf{2 f}$.

Concurrent with these studies, the effect of substitution on the pyridine ring of $\mathbf{2} \mathbf{f}$ was examined (Figure 5). Initially, a methyl scan of the pyridine subunit was performed with placement of a methyl group at each available site (3-, 4-, 5- and 6-positions). Whereas methyl substitution at the 3-position (15a) led to a modest 3-fold decrease in inhibitory potency, substitution at the 4-, 5- and 6-positions (15b-d) led to inhibitors that were 1.5 to 8 -fold more potent than the parent $\mathbf{2 f}$. With the optimal substitution being at the 4-position (15b), several additional substituents $(\mathbf{1 5 e}-\mathbf{j})$ were examined at this position and all led to modest increased inhibitory potency (up to 6-fold) compared to $\mathbf{2 f}$ (except $\mathbf{1 5 i}, 4-\mathrm{NH}_{2}$ ). None of the derivatives in this 4- 
substituted series $(\mathbf{1 5 a}-\mathbf{j})$ quite matched the potency of $\mathbf{1 5 b}\left(4-\mathrm{CH}_{3}\right)$ and, interestingly, this increased potency relative to $\mathbf{2 f}$ proved relatively independent of whether this 4-substituent was an electron-donating or electron-withdrawing group that might significantly alter the pyridyl nitrogen basicity and hydrogen-bond capability. Nonetheless and excluding $\mathbf{1 5 i}$, the substituent effects do roughly mirror a trend that might reflect their impact on the hydrogenbond acceptor capability of the pyridine nitrogen $\left(\mathrm{CH}_{3}, \mathrm{OCH}_{3}>\mathrm{CO}_{2} \mathrm{CH}_{3}, \mathrm{CN}, \mathrm{CF}_{3}, \mathrm{NO}_{2}\right)$, albeit within a narrow range and not with a rank order that strictly reflects the electronic properties of the pyridyl substituent.

Since the study with the substituted benzene derivatives (Figure 4) revealed that it was possible to place substituents in the meta-position of the benzene ring (13d, 13h, 13i) and obtain inhibitors that were more potent or equipotent to $\mathbf{2 f}$, we explored the addition of these substituents (e.g., $\mathrm{CO}_{2} \mathrm{CH}_{3}, \mathrm{CO}_{2} \mathrm{H}, \mathrm{CONH}_{2} ; \mathbf{1 5 k}-\mathbf{t}$ ) to the pyridine ring of $\mathbf{2} \mathbf{f}$ to establish whether this would lead to a further enhancement in inhibitory potency. As expected, substitution at the pyridyl 3-position (ortho-substitution) with either a methyl ester (15k) or carboxylic acid (15o) resulted in decreased inhibitory potency analogous to observations in the 12 series (Figure 4). Methyl ester substitution at the remaining positions provided inhibitors that were more potent than the corresponding phenyl series $(\mathbf{1 3 c}, \mathbf{1 4 c})$ with the 4- and 5substitution matching or exceeding the potency of $\mathbf{2 f}$ by 3 - and 1.3 -fold, respectively, and 6substitution approaching, but not enhancing, that of $\mathbf{2 f}$. Notably, this places the $\mathrm{C} 4$ methyl ester (15l) among the most potent of the 4-substituents and among the most potent inhibitors of the series. Importantly, this incorporation of the pyridine nitrogen into $13 \mathbf{c}$ and $14 \mathbf{c}$ enhances inhibitory potency 10 -fold, which is consistent with its proposed role as a hydrogen-bond acceptor approaching the 20 -fold enhancement observed with $\mathbf{2 f}$ versus phenyl derivative $\mathbf{2 i}$. Similarly, addition of a carboxamide to the pyridyl 5- (15s) or 6-position (15t) resulted in significant increases in inhibition (2.5- and 4-fold, respectively relative to $\mathbf{2 f}$ ), providing the most potent inhibitors in the series and compounds that are more than 5-fold more potent than the corresponding phenyl series (13i, 14i). Finally, the substitution of a carboxylic acid at the 4-, 5-, and 6-positions of $\mathbf{2 f}$ provided effective inhibitors of FAAH with $\mathbf{1 5 q}\left(5-\mathrm{CO}_{2} \mathrm{H}\right)$ and $15 \mathbf{r}\left(6-\mathrm{CO}_{2} \mathrm{H}\right)$ approaching the potency of $\mathbf{2 f}$. This is especially significant since the in vitro assays for FAAH inhibition are conducted at $\mathrm{pH} 9$ where the inhibitors are fully ionized likely masking their true inhibitory potency at physiological $\mathrm{pH}$. Thus, not only were many of the candidate inhibitors as potent or more potent than $\mathbf{2 f}$, but several of these compounds (15q15t) contain moieties that would be expected to productively alter the physicochemical properties of $\mathbf{2 f}$ (e.g., water solubility). With these observations, we examined the incorporation of these substituents on both the furan and thiophene rings of $2 \mathrm{~g}$ and $2 \mathbf{h}(\mathbf{1 6} \mathbf{a}-\mathbf{b}, \mathbf{1 7} \mathbf{a}-\mathbf{c})$. All led to similar or increased inhibitory potency as compared to parent inhibitors $\mathbf{2 g}$ or $\mathbf{2 h}$ of which $\mathbf{1 7} \mathbf{c}$ is notably eighteen times more potent than parent $\mathbf{2 h}$.

Additional aryl substituents that were examined in this study are summarized in Figure 6 and complement those disclosed (e.g., $\mathbf{1 8 a}-\mathbf{c}$ ) along with $\mathbf{2 f}$. ${ }^{45}$ The addition of methoxy groups to the pyrimidine ring of $18 \mathbf{a}$ and $\mathbf{1 8 c}(\mathbf{1 8 d}, \mathbf{1 8 e})$ had no effect on inhibitory potency relative to 18a and 18c. Tetrazole 18f experienced a 12-fold decrease in inhibitory potency compared to $\mathbf{2 f}$, although it is still more potent than phenyl derivative $\mathbf{2 i}$. A significant decrease in inhibitory potency was observed for dimer $\mathbf{1 8 g}$.

\section{Small, Non-Aromatic Substituents}

The results of the studies with the aryl substituents (vide supra), as well as previous studies,

45 indicated that typically electron-deficient aryl groups bearing substituents capable of hydrogen-bonding at the 5-position of the oxazole of these $\alpha$-ketoheterocycles are important for imparting low nanomolar inhibitory potency. As such, we were interested in establishing if this would be observed with non-aromatic substituents that were also capable of hydrogen- 
bonding. Consequently, a representative series of such candidate inhibitors bearing electronwithdrawing substituents was prepared and examined for FAAH inhibition (Figure 7). Although the carboxylic acid $\mathbf{2 0 b}$ led to only a small increase in inhibitory potency relative to 20a $(\mathrm{R}=\mathrm{H})$, all other carboxylic acid and ketone derivatives (20c-i, 20n) exhibited excellent inhibiton substantially exceeding the potency of 20a and approaching or exceeding the activity of $2 \mathbf{f}$ with 20n $\left(K_{\mathrm{i}}=400 \mathrm{pM}\right)$ emerging as a picomolar inhibitor. Notably, even though a 5fold loss of potency is observed with the carboxylic acid $\mathbf{2 0 b}$ as compared to $\mathbf{2} \mathbf{f}$ in an assay artificially conducted at $\mathrm{pH} 9, \mathbf{2 0 b}$ is still a very potent inhibitor of FAAH that qualitatively possesses different physicochemical properties (e.g., solubility) than 2f. A small, but systematic exploration of the amide derivatives $(\mathbf{2 0 j}-\mathbf{m})$ illustrated a smooth increase in inhibitory potency as the polarity of the 6-membered ring decreased. Analogous to prior observations, ${ }^{45}$ substitution on the oxazole with a 5 -methyl substitutent (20o) resulted in a significant loss in activity relative to $\mathbf{2 0 a}(\mathrm{R}=\mathrm{H})$. In contrast and unexpectedly, derivatives 20p-t which contain C5-substituents that are not regarded as hydrogen-bond acceptors all exhibited potencies greater than that of $\mathbf{2 0 a}(\mathrm{R}=\mathrm{H})$ and approaching or exceeding that of $\mathbf{2 f}$. Especially noteworthy was the observation that $20 \mathrm{p}\left(\mathrm{R}=\mathrm{CF}_{3}\right)$ exhibited extraordinarily potent inhibition of FAAH $\left(K_{\mathrm{i}}=800 \mathrm{pM}\right)$. Moreover, this series exhibited a well-defined trend for the halide substituents $\left(\mathrm{CF}_{3}>\mathrm{I} \geq \mathrm{Br}>\mathrm{Cl}>\mathrm{F}\right)$ that tracks with their electron-withdrawing properties. With this in mind, a correlation plot of the inhibition $\left(-\log K_{\mathrm{i}}\right)$ versus the Hammett $\boldsymbol{\sigma}_{\mathrm{p}}$ constant for this entire series was constructed (Figure 8). ${ }^{61}$ The activity of this series, which constitutes a set of relatively small substituents that can occupy accessible space in the FAAH active site, was found to follow a well-defined correlation with $\sigma_{p}\left(R^{2}=0.91\right)$ in which the electron-withdrawing substituents predictably enhance the inhibitory potency. In addition, this substituent effect was established to be large $(\rho=3.01)$ resulting in a 1000 -fold increase in $K_{\mathrm{i}}$ per unit change in $\boldsymbol{\sigma}_{\mathrm{p}}$ indicating that the electronic character of the substituent is the dominant factor contributing to the differences in binding affinity. Presumably, this arises from the increased electrophilic character of the $\mathrm{C} 2$ carbonyl imparted by the electron-withdrawing $\mathrm{C} 5$ substituent that leads to an increased strength of the covalent bond formed with the Ser $241 \mathrm{OH}$ enhancing the stability of the adduct and slowing the off-rate, thus lowering the $K_{\mathrm{i}}$ value. The definition of this fundamental relationship between the $K_{\mathrm{i}}$ and substituent property $\left(\boldsymbol{\sigma}_{\mathrm{p}}\right)$ permits the prediction of an expected $K_{\mathrm{i}}$ value. With confidence, we can assert that the carboxylic acid (20b) binds FAAH as the carboxylate anion $\left(\mathrm{CO}_{2}{ }^{-}\right.$vs $\mathrm{CO}_{2} \mathrm{H}, \boldsymbol{\sigma}_{\mathrm{p}}=0.11$ vs 0.44$)$ under the conditions of the assay (from the $K_{\mathrm{i}}$ value, $\mathrm{pH} 9$ ). Even more interestingly, we are able to establish that both the aldehyde 20i and trifluoromethyl ketone 20h exist in solution as gem diols (at $\mathrm{C} 5$, but not $\mathrm{C} 2 ;{ }^{1} \mathrm{H}$ and ${ }^{13} \mathrm{C}$ NMR, Supporting Information) and inhibit the enzyme with potencies $\left(K_{\mathrm{i}}=6\right.$ and $\left.3.5 \mathrm{nM}\right)$ at a level more consistent with this C5 substituent gem diol versus carbonyl active site binding and providing the first $\boldsymbol{\sigma}_{\mathrm{p}}$ estimates for such substituents $\left(0.26\right.$ for $\mathrm{CH}(\mathrm{OH})_{2}$ and 0.33 for $\left.\mathrm{C}(\mathrm{OH})_{2} \mathrm{CF}_{3}\right)$. On occasion, an anomalous $\sigma_{\mathrm{p}}$ of 0.22 is reported or used for - $\mathrm{CHO}$ (vs 0.42 ) that may more accurately reflect an analogous, but unrecognized gem diol. That is, the correlation between $\boldsymbol{\sigma}_{\mathrm{p}}$ and $K_{\mathrm{i}}$ is sufficiently dependable that deviations from expectations can be utilized to establish features of active site binding that are not a priori known. Similarly, with the correlation in hand, several of the potent inhibitors in Figure 7 were retrospectively prepared and examined based solely on this relationship. Notably, 20c, 20n and 20p bearing the strongest electron-withdrawing substituents display subnanomolar inhibitory potency. Aside from its role in establishing the potent FAAH inhibitors detailed herein, to our knowledge this also represents the first delineation of a fundamental substituent effect for such $\alpha$-ketoheterocycles that has eluded experimental verification ${ }^{78,79}$ in studies conducted to date. 80

While additional substituent features can and will further modulate the binding affinity of the candidate inhibitors (e.g., H-bonding, hydrophobic, or steric interactions), the magnitude of the electronic effect of the substituent $(\rho=3.01)$ on the activity of a conjugated $\alpha$ ketoheterocycle $\left(K_{\mathrm{i}}\right)$ suggests the latter will dominate, especially with small substituents. For 
example, if one tries to incorporate the $\mathbf{2 0} \mathbf{j}-\mathbf{m}$ carboxamide series into the correlation, each is significantly less potent than predicted indicating that the larger six-membered ring amides embody steric (20j-m) and additional hydrophilic $(\mathbf{2 0 j}$ and $\mathbf{2 0 k})$ characteristics that incrementally destabilize inhibitor binding. More interestingly, placing the larger phenyl $\left(K_{\mathrm{i}}\right.$ $=80 \mathrm{nM}, \sigma_{\mathrm{p}}=0.05$ or -0.01$), 2$-furyl $\left(K_{\mathrm{i}}=12 \mathrm{nM}, \boldsymbol{\sigma}_{\mathrm{p}}=0.02\right), 2$-thienyl $\left(K_{\mathrm{i}}=55 \mathrm{nM}, \boldsymbol{\sigma}_{\mathrm{p}}=\right.$ $0.05)$, and 2-pyridyl $\left(K_{\mathrm{i}}=4.7 \mathrm{nM}, \boldsymbol{\sigma}_{\mathrm{p}}=0.17\right)$ substituents (disclosed in ref. ${ }^{45}$ ) on the correlation plot (Figure 9) revealed several interesting features. The 2-pyridyl and 2-thienyl substituents appear to fit the correlation well, but this may in fact be misleading. The phenyl substituent, which is larger than the substituents depicted in Figure 8, exhibits a $K_{\mathrm{i}}$ notably weaker than the correlation would predict. However, even here and with the choice of $\sigma_{\mathrm{p}}=-0.01$ (vs 0.05), it provides a correlation that is not unreasonable. Although there may be several explanations for this behavior, we have interpreted this to indicate that there may be destabilizing (presumably steric) interactions that accompany binding of such a large C5 substituent in the active site. In contrast, the 2-thienyl (slightly weaker than predicted) and 2-pyridyl (slightly more potent than predicted) substituents exhibit $K_{\mathrm{i}}$ 's that appear to be predicted by the correlation, but are anomalous when compared to the phenyl or furyl substituent. We attribute this to a key stabilizing active site hydrogen bond (discussed earlier in modeling studies, ref. 45 ) which compensates for the destabilizing steric interactions progressively enhancing the potency of the inhibitors bearing the 2-thienyl and 2-pyridyl substituents such that 2-thienyl approaches and 2-pyridyl exceeds the correlation prediction. Consistent with this, the 2-furyl substituent also positively deviates from the correlation consistent with its relative $\mathrm{H}$-bonding capabilities. Interestingly, the H-bonded pyridyl nitrogen (partial protonation) would make this substituent a stronger electron-withdrawing substituent. Whether the productive deviation of the 2-pyridyl substituent is best interpreted simply as benefiting from an additional stabilizing H-bond, or whether this represents an enhanced electronic effect of the H-bonded substituent is not a question that can be answered with this study. However, it does suggest that the modeled ${ }^{45} \mathrm{H}$-bonded array is responsible for its improved potency and productive deviation from the correlation. Importantly, its deviation from the correlation does not negate the correlation, and the correlation does not negate the prior modeling observations with the 2pyridyl substituent. Rather, its productive deviation from the correlation highlights a special character of this substituent and allows the identification of active site binding features that are not a priori known. Similarly, the substituted phenyl (12-14) and pyridyl series (15) series cluster in regions surrounding the parent phenyl or pyridyl substituent. The latter series exhibits less variation in the $K_{\mathrm{i}}$, whereas the former exhibits a greater variation and the trends reflect the expected impact of an added electron-withdrawing substituent, albeit within a range where it is further modulated by additional features that affect binding site affinity.

Finally, two uracil derivatives $(20 v, 20 w)$ were also examined in this series and only $20 \mathrm{v}$ exhibited excellent inhibitory potency.

\section{The Electrophilic Carbonyl}

Consistent with past observations, ${ }^{45}$ the alcohol precursors to several of the $\alpha$-ketoheterocycles (21a-l) were examined and found to be approximately $10^{4}-10^{3}$ times less potent than the corresponding ketone (Figure 10). However, it should be noted that in many instances DMSO stock solutions of compounds 21a-21l were reevaluated by analytical LCMS after biological testing and were found to contain small $(0.1 \%)$ amounts of a material that was consistent in mass and retention time to the corresponding ketone and that increased in relative amount upon sample storage. In other cases, the ketone peak was not seen (detection limits of ca. $0.02 \%$ ). Given the very high potency of the ketones $\left(10^{3}\right.$ to $10^{4}$-fold more potent than the alcohols) and the tendency of the alcohols to slowly autooxidize to the corresponding ketones (data not shown), it is beyond current technical and analytical detection limits to conclusively rule out 
the possibility that the activity of these alcohol samples is due to trace amounts of ketone impurities.

\section{Inhibition of Recombinant Human FAAH}

Rat and human FAAH are very homologous (84\% sequence identity), exhibit near identical substrate selectivities and inhibitor sensitivities in studies disclosed to date, ${ }^{47}$ and embody an identical amidase signature sequence suggesting the observations made with rat FAAH would be analogous to those made with the human enzyme. Consequently, key inhibitors in the series were examined against the human enzyme and consistent with previous observations 45 were found to exhibit the same relative and absolute potencies (Figure 11).

\section{Selectivity Screening}

Early assessments of $\alpha$-ketoheterocycle inhibitors of FAAH against possible competitive enzymes (e.g., phospholipase A2, ceramidase) revealed no inhibition. Consequently a method for proteomic-wide screening capable of globally profiling all mammalian serine hydrolases was developed 69 and studies have shown that the $\alpha$-ketoheterocycle class of inhibitors are exquisitely selective for FAAH. ${ }^{45,62,66}$ However, two enzymes did emerge as potential competitive targets: triacylglycerol hydrolase (TGH) and an uncharacterized membraneassociated hydrolase that lacks known substrates or function (KIAA1363). In this screen, $\mathrm{IC}_{50}$ values are typically higher than the measured $K_{\mathrm{i}}$ values, but the relative potency, the magnitude of binding affinity differences and the rank order binding determined in the assay parallels that established by standard substrate assays.

Summarized in Figure 12 are the results of the selectivity screening of selected candidate inhibitors. In general, these new $\alpha$-ketoheterocycle inhibitors were very selective for FAAH over TGH and KIAA1361 except 13h, 18d, 18e 20a and 20r, which were selective for TGH. Thus, substitution at the $\mathrm{C} 5$ oxazole position with either aromatic or non-aromatic substituents provides selective inhibitors compared to unsubstituted 20a which itself is 100-fold selective for TGH over FAAH. Consistent with prior observations, incorporation of a substituted 2pyridyl group at C5 provided superb selectivities ( $\mathbf{1 5}$ series, $>100$-fold selective) analogous to that observed with $\mathbf{2 f}$ itself, whereas the incorporation of substituted phenyl groups (13 series) or non-aryl substituents (20 series) at C5 provided more modest FAAH selectivities. Most notably, substitution of a carboxylic acid either directly on the oxazole ring (20b) or on the 5aryl moiety $(\mathbf{1 3 d}, \mathbf{1 5 q}, \mathbf{1 5 r}, \mathbf{1 6} \mathbf{b})$ appears to impart even greater selectivity for FAAH providing inhibitors (>50-1000 fold selectivity) that fail to inhibit either TGH or KIAA1363. Notably, this reversal of selectivity from $20 \mathbf{a}\left(>10^{4}\right.$ change in relative activity) occurs with both increases in affinity for FAAH and disruption of affinity for TGH and KIAA1363, both of which are effectively assessed and optimized (multidimensional SAR) with the proteome-wide selectivity screening.

\section{Conclusion}

A series of 5-substituted 7-phenyl-1-(oxazol-2-yl)heptan-1-ones were prepared and evaluated for FAAH inhibitory potency as well as FAAH selectivity versus competitive serine proteases (e.g., TGH, KIA1363). Aromatic and non-aromatic substituents were explored on the 5position of the oxazole of $\mathbf{2} \mathbf{f}$ and many of these inhibitors approached or substantially exceeded its potency. Just as importantly, proteome-wide selectivity screening of the candidate inhibitors showed extraordinary selectivity for FAAH over all other serine hydrolases and proteases. Thus, addition of a C5 substituent to $\mathbf{2 0 a}(\mathrm{R}=\mathrm{H})$, which is 100 -fold selective for TGH, results in inhibitors now selective for FAAH versus TGH. Most notable of these is the addition of a carboxylic acid either directly on the oxazole (20b) or on the 5-aryl group (e.g., 15r) which imparts a 100-1000 fold selectivity for FAAH. For small, non-aryl substituents, a fundamental 
relationship between the $K_{\mathrm{i}}$ and the electronic character of the substituent $\left(\boldsymbol{\sigma}_{\mathrm{p}}\right)$ was defined that not only permits a prediction of the expected $K_{\mathrm{i}}$, but also led to the design of FAAH inhibitors with $K_{\mathrm{i}}$ 's as low as $400 \mathrm{pM}$. Finally, several of these inhibitors $(\mathbf{1 5 q}-\mathbf{t}, \mathbf{2 0 b})$ contain substituents that would be expected to productively alter the physicochemical properties of $\mathbf{2 f}$ and will facilitate their in vivo exploration.

\section{Experimental}

\section{6-(2-(7-Phenylheptanoyl)oxazol-5-yl)picolinic acid (15r)}

2-(1-(tert-Butyldimethylsilyloxy)-7-phenylheptyl)-5-(tributylstannyl)oxazole ${ }^{47}(\mathbf{5}, 1.27 \mathrm{~g}$, $1.92 \mathrm{mmol}), \mathrm{Pd}\left(\mathrm{PPh}_{3}\right)_{4}(221 \mathrm{mg}, 0.191 \mathrm{mmol})$, and methyl 6-chloropicolinate $(658 \mathrm{mg}, 3.83$ $\mathrm{mmol}$ ) were dissolved in anhydrous 1,4-dioxane $(40 \mathrm{~mL})$ and the mixture was warmed at reflux for $24 \mathrm{~h}$ under Ar. The mixture was diluted with EtOAc, washed with saturated aqueous $\mathrm{NaCl}$ and dried over $\mathrm{Na}_{2} \mathrm{SO}_{4}$. Evaporation in vacuo yielded the crude product. Flash chromatography $\left(\mathrm{SiO}_{2}, 5-10 \% \mathrm{EtOAc} /\right.$ hexanes) yielded methyl 6-(2-(1-(tert-butyldimethylsilyloxy)-7phenylheptyl)oxazol-5-yl)picolinate as a clear oil (975 mg, 100\%): ${ }^{1} \mathrm{H} \mathrm{NMR}\left(\mathrm{CDCl}_{3}, 500\right.$ MHz) $\delta 8.12-8.10(\mathrm{~m}, 1 \mathrm{H}), 7.99(\mathrm{t}, 1 \mathrm{H}, J=7.8 \mathrm{~Hz}), 7.90-7.89(\mathrm{~m}, 1 \mathrm{H}), 7.86(\mathrm{~s}, 1 \mathrm{H}), 7.35-$ $7.32(\mathrm{~m}, 2 \mathrm{H}), 7.25-7.22(\mathrm{~m}, 3 \mathrm{H}), 4.94(\mathrm{t}, 1 \mathrm{H}, J=7.0 \mathrm{~Hz}), 4.10(\mathrm{~s}, 3 \mathrm{H}), 2.67(\mathrm{t}, 2 \mathrm{H}, J=7.5$ $\mathrm{Hz}), 2.04-1.96(\mathrm{~m}, 2 \mathrm{H}), 1.74-1.67(\mathrm{~m}, 2 \mathrm{H}), 1.55-1.39(\mathrm{~m}, 6 \mathrm{H}), 0.97(\mathrm{~s}, 9 \mathrm{H}), 0.17(\mathrm{~s}, 3 \mathrm{H}), 0.07$ (s, $1 \mathrm{H}) ;{ }^{13} \mathrm{C} \mathrm{NMR}\left(\mathrm{CDCl}_{3}, 125 \mathrm{MHz}\right) \delta 166.5,165.8,150.3,148.7,148.2,143.3,138.4,128.8$, 128.6, 126.8, 126.0, 124.3, 122.5, 69.2, 53.4, 36.8, 36.3, 31.8, 29.6, 26.1, 26.1, 25.5, 14.0, -4.5, -4.7 .

Methyl 6-(2-(1-(tert-butyldimethylsilyloxy)-7-phenylheptyl)oxazol-5-yl)picolinate (1.95 g, $1.51 \mathrm{mmol})$ was dissolved in THF $(30 \mathrm{~mL})$, treated with $\mathrm{Bu}_{4} \mathrm{NF}(1 \mathrm{M}$ in THF, $4.6 \mathrm{~mL}, 1.81$ $\mathrm{mmol}$ ) and stirred at room temperature for $2 \mathrm{~h}$ under Ar. The reaction mixture was diluted with EtOAc, washed with saturated aqueous $\mathrm{NaCl}$ and dried over $\mathrm{Na}_{2} \mathrm{SO}_{4}$. Evaporation in vacuo yielded the crude alcohol, which was filtered through a short silica gel pad. The silica gel pad was washed with $10 \% \mathrm{EtOAc} /$ hexanes followed by $60 \% \mathrm{EtOAc} / \mathrm{hexanes}$ to afford the alcohol $(1.24 \mathrm{~g}, 82 \%)$, which required no further purification. The alcohol (1.24 g, $3.14 \mathrm{mmol})$ was dissolved in $\mathrm{CH}_{2} \mathrm{Cl}_{2}(25 \mathrm{~mL})$ and Dess-Martin periodinane $(2.0 \mathrm{~g}, 4.72 \mathrm{mmol})$ was added. The mixture was stirred at room temperature for $2 \mathrm{~h}$ before silica gel was added and the reaction mixture was evaporated in vacuo to afford the crude ketone absorbed on silica gel. Flash chromatography $\left(\mathrm{SiO}_{2}, 10-30 \%\right.$ EtOAc) yielded methyl 6-(2-(7-phenylheptanoyl)oxazol-5yl)picolinate (15n) as a white solid $(1.13 \mathrm{~g}, 91 \%)$ : $\mathrm{mp} 50-51{ }^{\circ} \mathrm{C} ;{ }^{1} \mathrm{H} \mathrm{NMR}\left(\mathrm{CDCl}_{3}, 500 \mathrm{MHz}\right)$ $\delta 8.19(\mathrm{~d}, 1 \mathrm{H}, J=7.0 \mathrm{~Hz}), 8.12-8.09(\mathrm{~m}, 2 \mathrm{H}), 8.06-8.03(\mathrm{~m}, 1 \mathrm{H}), 7.36-7.33(\mathrm{~m}, 2 \mathrm{H}), 7.26-$ $7.24(\mathrm{~m}, 3 \mathrm{H}), 4.11(\mathrm{~s}, 3 \mathrm{H}), 3.19(\mathrm{t}, 2 \mathrm{H}, J=7.0 \mathrm{~Hz}), 2.69(\mathrm{t}, 2 \mathrm{H}, J=7.5 \mathrm{~Hz}), 1.89-1.83(\mathrm{~m}$, $2 \mathrm{H}), 1.75-1.69(\mathrm{~m}, 2 \mathrm{H}), 1.55-1.47(\mathrm{~m}, 4 \mathrm{H}) ;{ }^{13} \mathrm{C} \mathrm{NMR}\left(\mathrm{CDCl}_{3}, 125 \mathrm{MHz}\right) \delta 188.9,165.5$, 158.0, 152.7, 149.0, 147.0, 143.1, 138.7, 128.8, 128.7, 128.4, 126.0, 125.6, 123.7, 53.5, 39.6, 36.3, 31.7, 29.4, 29.4, 24.3; ESI-TOF $m / z 393.1796\left(\mathrm{M}+\mathrm{H}^{+}, \mathrm{C}_{23} \mathrm{H}_{25} \mathrm{~N}_{2} \mathrm{O}_{4}\right.$, requires 393.1809).

Methyl 6-(2-(7-phenylheptanoyl)oxazol-5-yl)picolinate (15n, $1.13 \mathrm{~g}, 2.88 \mathrm{mmol})$ was dissolved in a mixture of $3: 2 \mathrm{THF} / \mathrm{H}_{2} \mathrm{O}(48 \mathrm{~mL}: 32 \mathrm{~mL})$ and $\mathrm{LiOH}(360 \mathrm{mg}, 8.64 \mathrm{mmol})$ was added. The reaction mixture was stirred for $2 \mathrm{~h}$ at room temperature before the mixture was made acidic with the addition of aqueous $1 \mathrm{~N} \mathrm{HCl}$. The solution was diluted with EtOAc and the organic layer was separated from the aqueous layer. The aqueous layer was extracted with EtOAc (3x). The combined organic extracts were washed with saturated aqueous $\mathrm{NaCl}$ and dried over $\mathrm{Na}_{2} \mathrm{SO}_{4}$. Evaporation in vacuo yielded the crude acid. Flash chromatography $\left(\mathrm{SiO}_{2}, 0-2 \% \mathrm{AcOH} / \mathrm{EtOAc}\right)$ yielded $15 \mathrm{r}$ as a white solid $(991 \mathrm{mg}, 91 \%): \mathrm{mp} 119-120{ }^{\circ} \mathrm{C} ;{ }^{1} \mathrm{H}$ NMR (THF- $\left.d_{8}, 500 \mathrm{MHz}\right) \delta 8.11-8.04(\mathrm{~m}, 4 \mathrm{H}), 7.22-7.08(\mathrm{~m}, 5 \mathrm{H}), 3.08(\mathrm{t}, 2 \mathrm{H}, J=7.5 \mathrm{~Hz})$, $2.61(\mathrm{t}, 2 \mathrm{H}, J=7.5 \mathrm{~Hz}), 1.76-1.68(\mathrm{~m}, 2 \mathrm{H}), 1.68-1.62(\mathrm{~m}, 2 \mathrm{H}), 1.45-1.41(\mathrm{~m}, 4 \mathrm{H}) ;{ }^{13} \mathrm{C}$ NMR (THF- $\left.d_{8}, 125 \mathrm{MHz}\right) \delta 185.6,163.1,156.4,151.4,147.6,144.7,141.0,137.1,126.7,126.5$, 
126.1, 123.9, 122.8, 121.1, 37.1, 34.3, 30.0, 27.6, 27.5, 22.2; ESI-TOF $m / z 379.1645(\mathrm{M}+$ $\mathrm{H}^{+}, \mathrm{C}_{22} \mathrm{H}_{23} \mathrm{~N}_{2} \mathrm{O}_{4}$, requires 379.1652).

\section{2-(7-Phenylheptanoyl)oxazole-5-carboxylic acid (20b)}

2-(1-(tert-Butyldimethylsilyloxy)-7-phenylheptyl)oxazole ${ }^{47}(4,970 \mathrm{mg}, 2.60 \mathrm{mmol})$ was dissolved in anhydrous THF $(20 \mathrm{~mL})$, cooled to $-78{ }^{\circ} \mathrm{C}$ and $t-\mathrm{BuLi}(1.7 \mathrm{M}$ in pentane, 1.99 $\mathrm{mL}, 3.38 \mathrm{mmol}$ ) was added dropwise under Ar. The reaction mixture was stirred for $2 \mathrm{~h}$ at -40 ${ }^{\circ} \mathrm{C}$, recooled to $-78{ }^{\circ} \mathrm{C}$ and $\mathrm{CO}_{2}(\mathrm{~g})$ was bubbled through the solution for $1 \mathrm{~h}$. The reaction mixture was warmed to room temperature, diluted with EtOAc, washed with saturated aqueous $\mathrm{NaCl}$ and dried over $\mathrm{Na}_{2} \mathrm{SO}_{4}$. Evaporation in vacuo yielded the crude acid which was purified by flash chromatography $\left(\mathrm{SiO}_{2}, 0-2 \% \mathrm{AcOH} / \mathrm{EtOAc}\right.$ gradient elution) to afford 2-(1-(tertbutyldimethylsilyloxy)-7-phenylheptyl)oxazole-5-carboxylic acid as a clear oil (921 mg, 85\%): ${ }^{1} \mathrm{H}$ NMR $\left(\mathrm{CDCl}_{3}, 500 \mathrm{MHz}\right) \delta 7.91(\mathrm{~s}, 1 \mathrm{H}), 7.37-7.34(\mathrm{~m}, 2 \mathrm{H}), 7.27-7.25(\mathrm{~m}, 3 \mathrm{H})$, $4.98(\mathrm{t}, 1 \mathrm{H}, J=7.0 \mathrm{~Hz}), 2.69(\mathrm{t}, 2 \mathrm{H}, J=7.5 \mathrm{~Hz}), 2.07-1.94(\mathrm{~m}, 2 \mathrm{H}), 1.72-1.69(\mathrm{~m}, 2 \mathrm{H}), 1.52-$ $1.44(\mathrm{~m}, 6 \mathrm{H}), 0.99(\mathrm{~s}, 9 \mathrm{H}), 0.18(\mathrm{~s}, 3 \mathrm{H}), 0.09(\mathrm{~s}, 3 \mathrm{H}) ;{ }^{13} \mathrm{C} \mathrm{NMR}\left(\mathrm{CDCl}_{3}, 125 \mathrm{MHz}\right) \delta 169.3$, 161.5, 143.1, 139.2, 134.5, 128.8, 128.7, 126.0, 126.3, 69.0, 36.8, 36.4, 31.8, 29.5, 26.1, 26.1, $25.4,18.6,-4.6,-4.8$.

2-(1-(tert-Butyldimethylsilyloxy)-7-phenylheptyl)oxazole-5-carboxylic acid (921 mg, 2.21 mmol) was dissolved in a mixture of $\mathrm{MeOH}$ :toluene $(8 \mathrm{~mL}: 20 \mathrm{~mL})$, cooled to $0{ }^{\circ} \mathrm{C}$ and $\mathrm{TMSCHN}_{2}$ (2 M in hexanes, $2.76 \mathrm{~mL}, 5.51 \mathrm{mmol}$ ) was added dropwise under Ar. The reaction mixture was stirred at room temperature for $0.5 \mathrm{~h}$ before it was cooled to $0{ }^{\circ} \mathrm{C}$. Acetic acid was added dropwise until the solution turned from yellow to clear and bubbling ceased. The mixture was evaporated in vacuo and the resulting solid was dissolved in EtOAc. The solution was washed with saturated aqueous $\mathrm{NaHCO}_{3}$, washed with saturated aqueous $\mathrm{NaCl}$ and dried over $\mathrm{Na}_{2} \mathrm{SO}_{4}$. Evaporation in vacuo yielded the crude product which was purified by flash chromatography $\left(\mathrm{SiO}_{2}, 10-30 \% \mathrm{EtOAc/hexanes)}\right.$ to afford methyl 2-(1-(tertbutyldimethylsilyloxy)-7-phenylheptyl)oxazole-5-carboxylate as a white solid (831 mg, 90\%): $\mathrm{mp} 38-39{ }^{\circ} \mathrm{C} ;{ }^{1} \mathrm{H}$ NMR $\left(\mathrm{CDCl}_{3}, 500 \mathrm{MHz}\right) \delta 7.78(\mathrm{~s}, 1 \mathrm{H}), 7.36-7.33(\mathrm{~m}, 2 \mathrm{H}), 7.25-7.23(\mathrm{~m}$, $3 \mathrm{H}), 4.92(\mathrm{t}, 1 \mathrm{H}, J=7.0 \mathrm{~Hz}), 3.98(\mathrm{~s}, 3 \mathrm{H}), 2.67(\mathrm{t}, 2 \mathrm{H}, J=7.5 \mathrm{~Hz}), 2.12-1.94(\mathrm{~m}, 2 \mathrm{H}), 1.72-$ $1.67(\mathrm{~m}, 2 \mathrm{H}), 1.53-1.43(\mathrm{~m}, 6 \mathrm{H}), 0.98(\mathrm{~s}, 9 \mathrm{H}), 0.17(\mathrm{~s}, 3 \mathrm{H}), 0.08(\mathrm{~s}, 3 \mathrm{H}) ;{ }^{13} \mathrm{C} \mathrm{NMR}\left(\mathrm{CDCl}_{3}\right.$, $125 \mathrm{MHz}) \delta 169.0,158.5,143.1,142.6,134.5,128.8,128.6,126.0,69.1,52.5,36.7,36.3,31.8$, $29.5,26.1,26.1,25.4,18.6,-4.6,-4.8$.

Methyl 2-(1-(tert-butyldimethylsilyloxy)-7-phenylheptyl)oxazole-5-carboxylate (831 mg, $2.62 \mathrm{mmol})$ was dissolved in THF $(10 \mathrm{~mL})$, treated with $\mathrm{Bu}_{4} \mathrm{NF}(1 \mathrm{M}$ in THF, $2.31 \mathrm{~mL}, 3.14$ $\mathrm{mmol}$ ) and stirred at room temperature for $2 \mathrm{~h}$ under Ar. The reaction mixture was diluted with EtOAc, washed with saturated aqueous $\mathrm{NaCl}$ and dried over $\mathrm{Na}_{2} \mathrm{SO}_{4}$. Evaporation in vacuo yielded the crude alcohol, which was filtered through a short silica gel pad. The silica gel pad was washed with $10 \% \mathrm{EtOAc/hexanes} \mathrm{followed} \mathrm{by} 60 \% \mathrm{EtOAc} / \mathrm{hexanes}$ to afford the alcohol (559 mg, 91\%) which required no further purification. The alcohol (544 mg, $1.71 \mathrm{mmol}$ ) was dissolved in $\mathrm{CH}_{2} \mathrm{Cl}_{2}(10 \mathrm{~mL})$ and Dess-Martin periodinane $(1.09 \mathrm{~g}, 2.57 \mathrm{mmol})$ was added. The mixture was stirred at room temperature for $2 \mathrm{~h}$ before silica gel was added and the reaction mixture was evaporated in vacuo to afford the crude ketone absorbed on silica gel. Flash chromatography $\left(\mathrm{SiO}_{2}, 5-20 \%\right.$ EtOAc/hexanes) yielded methyl 2-(7-phenylheptanoyl) oxazole-5-carboxylate (20c) as a white solid (473 mg, 87\%): $\mathrm{mp} 90-91{ }^{\circ} \mathrm{C} ;{ }^{1} \mathrm{H}$ NMR $\left(\mathrm{CDCl}_{3}, 400 \mathrm{MHz}\right) \delta 7.84(\mathrm{~s}, 1 \mathrm{H}), 7.25-7.21(\mathrm{~m}, 2 \mathrm{H}), 7.15-7.12(\mathrm{~m}, 3 \mathrm{H}), 3.93(\mathrm{~s}, 3 \mathrm{H}), 3.04$ $(\mathrm{t}, 2 \mathrm{H}, J=7.5 \mathrm{~Hz}), 2.57(\mathrm{t}, 2 \mathrm{H}, J=7.5 \mathrm{~Hz}), 1.76-1.68(\mathrm{~m}, 2 \mathrm{H}), 1.63-1.56(\mathrm{~m}, 2 \mathrm{H}), 1.42-1.32$ $(\mathrm{m}, 4 \mathrm{H}) ;{ }^{13} \mathrm{C} \mathrm{NMR}\left(\mathrm{CDCl}_{3}, 100 \mathrm{MHz}\right) \delta 188.4,158.5,157.7,143.9,142.8,134.8,128.6,128.4$, 125.8, 53.0, 39.7, 36.0, 31.4, 29.1, 29.1, 23.7; ESI-TOF $m / z 316.1533\left(\mathrm{M}+\mathrm{H}^{+}\right.$, $\mathrm{C}_{18} \mathrm{H}_{22} \mathrm{NO}_{4}$, requires 316.1543). 
Methyl 2-(7-phenylheptanoyl)oxazole-5-carboxylate (20c, $71 \mathrm{mg}, 0.225 \mathrm{mmol}$ ) was dissolved in a mixture of 3:2 THF/ $\mathrm{H}_{2} \mathrm{O}(6 \mathrm{~mL}: 4 \mathrm{~mL})$ and $\mathrm{LiOH}(28 \mathrm{mg}, 0.672 \mathrm{mmol})$ was added. The reaction mixture stirred for $2 \mathrm{~h}$ at room temperature before the mixture was made acidic with the addition of aqueous $1 \mathrm{~N} \mathrm{HCl}$. The solution was diluted with EtOAc and the organic layer was separated from the aqueous layer. The aqueous layer was extracted with EtOAc. The combined organic extracts were washed with saturated aqueous $\mathrm{NaCl}$ and dried over $\mathrm{Na}_{2} \mathrm{SO}_{4}$. Evaporation in vacuo yielded the crude acid. Flash chromatography $\left(\mathrm{SiO}_{2}, 0-2 \%\right.$ $\mathrm{AcOH} / \mathrm{EtOAc}$ gradient elution) yielded $20 \mathrm{~b}$ as a white solid $(60 \mathrm{mg}, 88 \%)$ : $\mathrm{mp} 47-48{ }^{\circ} \mathrm{C} ;{ }^{1} \mathrm{H}$ NMR $\left(\mathrm{CD}_{3} \mathrm{OD}, 600 \mathrm{MHz}\right) \delta 7.62(\mathrm{~s}, 1 \mathrm{H}), 7.22-7.19(\mathrm{~m}, 2 \mathrm{H}), 7.14-7.09(\mathrm{~m}, 3 \mathrm{H}), 3.04(\mathrm{t}, 2 \mathrm{H}$, $J=7.5 \mathrm{~Hz}), 2.58(\mathrm{t}, 2 \mathrm{H}, J=7.5 \mathrm{~Hz}), 1.71-1.68(\mathrm{~m}, 2 \mathrm{H}), 1.62-1.59(\mathrm{~m}, 2 \mathrm{H}), 1.41-1.32(\mathrm{~m}$, $4 \mathrm{H}) ;{ }^{13} \mathrm{C}$ NMR $\left(\mathrm{CD}_{3} \mathrm{OD}, 150 \mathrm{MHz}\right) \delta 189.0,159.4,159.4,143.3,143.3,134.6,128.9,128.7$, 126.1, 39.6, 36.3, 32.0, 29.5, 29.4, 23.9; ESI-TOF $m / z 302.1382\left(\mathrm{M}+\mathrm{H}^{+}, \mathrm{C}_{17} \mathrm{H}_{20} \mathrm{NO}_{4}\right.$, requires 302.1387).

\section{FAAH Inhibition}

${ }^{14} \mathrm{C}$-labeled oleamide was prepared from ${ }^{14} \mathrm{C}$-labeled oleic acid as described. ${ }^{4,55}$ The truncated rat FAAH (rFAAH) was expressed in E. coli and purified as described. ${ }^{76}$ The purified recombinant rFAAH was used in the inhibition assays unless otherwise indicated. The fulllength human FAAH (hFAAH) was expressed in COS-7 cells as described, ${ }^{32}$ and the lysate of hFAAH-transfected COS-7 cells was used in the inhibition assays where explicitly indicated.

The inhibition assays were performed as described. ${ }^{4,55}$ In brief, the enzyme reaction was initiated by mixing $1 \mathrm{nM}$ of rFAAH $\left(800,500\right.$, or $200 \mathrm{pM} \mathrm{rFAAH}$ for inhibitors with $K_{\mathrm{i}} \leq 1-$ $2 \mathrm{nM})$ with $10 \mu \mathrm{M}$ of ${ }^{14} \mathrm{C}$-labeled oleamide in $500 \mu \mathrm{L}$ of reaction buffer $(125 \mathrm{mM}$ TrisCl, 1 mM EDTA, $0.2 \%$ glycerol, $0.02 \%$ Triton X-100, $0.4 \mathrm{mM}$ Hepes, $\mathrm{pH}$ 9.0) at room temperature in the presence of three different concentrations of inhibitor. The enzyme reaction was terminated by transferring $20 \mu \mathrm{L}$ of the reaction mixture to $500 \mu \mathrm{L}$ of $0.1 \mathrm{~N} \mathrm{HCl}$ at three different time points. The ${ }^{14} \mathrm{C}$-labeled oleamide (substrate) and oleic acid (product) were extracted with EtOAc and analyzed by TLC as detailed. ${ }^{4,55}$ The $K_{\mathrm{i}}$ of the inhibitor was calculated using a Dixon plot as described (standard deviations are provided in the Supporting Information tables). ${ }^{47}$ Lineweaver-Burk analysis was performed as described, ${ }^{4,55}$ in the presence or absence of $8 \mathrm{nM}$ of $\mathbf{2 f}$, respectively, confirming competitive, reversible inhibition. ${ }^{45}$

\section{Selectivity Screening}

The selectivity screening was conducted as detailed. 69

\section{Supplementary Material}

Refer to Web version on PubMed Central for supplementary material.

\section{Acknowledgements}

We gratefully acknowledge the financial support of the National Institutes of Health (DA15648, D.L.B.; DA017259 and DA015197, B.F.C.) and the Skaggs Institute for Chemical Biology, and the postdoctoral fellowship support for F.A.R. (American Cancer Society).

\section{Abbreviations}

FAAH

fatty acid amide hydrolase

TGH

triacylglycerol hydrolase 


\section{References}

1. Devane WA, Hanus L, Breuer A, Pertwee RG, Stevenson LA, Griffin G, Gibson D, Mandelbaum A, Etinger A, Mechoulam R. Isolation and Structure of a Brain Constituent that Binds to the Cannabinoid Receptor. Science 1992;258:1946-1949. [PubMed: 1470919]

2. Boger DL, Henriksen SJ, Cravatt BF. Oleamide: An Endogenous Sleep-Inducing Lipid and Prototypical Member of a New Class of Lipid Signalling Molecules. Curr Pharm Des 1998;4:303314. [PubMed: 10197045]

3. Cravatt BF, Lerner RA, Boger DL. Structure Determination of an Endogenous Sleep-Inducing Lipid, cis-9-Octadecenamide (Oleamide): A Synthetic Approach to the Chemical Analysis of Trace Quantitites of a Natural Product. J Am Chem Soc 1996;118:580-590.

4. Cravatt BF, Prospero-Garcia O, Suizdak G, Gilula NB, Henriksen SJ, Boger DL, Lerner RA. Chemical Characterization of a Family of Brain Lipids that Induce Sleep. Science 1995;268:1506-1509. [PubMed: 7770779]

5. Schmid HHO, Schmid PC, Natarajan V. N-Acylated Glycerophospholipids and Their Derivatives. Prog Lipid Res 1990;29:1-43. [PubMed: 2087478]

6. Lambert DM, Fowler CJ. The Endocannabinoid System: Drug Targets, Lead Compounds, and Potential Therapeutic Applications. J Med Chem 2005;48:5059-5087. [PubMed: 16078824]

7. Calignano A, La Rana G, Giuffrida A, Piomelli D. Control of Pain Initiation by Endogenous Cannabinoids. Nature 1998;394:277-281. [PubMed: 9685157]

8. Cravatt BF, Lichtman AH. The Endogenous Cannabinoid System and Its Role in Nociceptive Behavior. J Neurobiol 2004;61:149-160. [PubMed: 15362158]

9. Walker JM, Huang SM, Stragman NM, Tsou K, Sanudo-Pena MC. Pain Modulation by Release of the Endogenous Cannabinoid Anamdamide. Proc Natl Acad Sci US A 1999;96:12198-12203.

10. Gomez R, Navarro M, Ferrer B, Trigo JM, Bilbao A, Del Arco I, Cippitelli A, Nava F, Piomelli D, Rodríguez de Fonseca F. A Peripheral Mechanism for CB1 Cannabinoid Receptor Dependent Modulation of Feeding. J Neurosci 2002;22:9612-9617. [PubMed: 12417686]

11. Williams CM, Kirkham TC. Observational Analysis of Feeding Induced by -THC and Anandamide. Physiol Behav 2002;76:241-250. [PubMed: 12044596]

12. Kathuria S, Gaetani S, Fegley D, Valino F, Duranti A, Tontini A, Mor M, Tarzia G, La Rana G, Calignano A, Giustino A, Tattoli M, Palmery M, Cuomo V, Piomelli D. Modulation of Anxiety Through Blockade of Anandamide Hydrolysis. Nat Med 2003;9:76-81. [PubMed: 12461523]

13. Melck D, Rueda D, Galve-Roberh I, De Petrocellis L, Guzmán M, Di MV. Involvement of the cAMP/ Protein Kinase A Pathway and of Mitogen-Activated Protein Kinase in the Anti-Proliferative Effects of Anandamide in Human Breast Cancer Cells. FEBS Lett 1999;463:235-240. [PubMed: 10606728]

14. Yamaji K, Sarker KP, Kawahara K, Iino S, Yamakuchi M, Abeyama K, Hashiguchi T, Maruyama I. Anandamide Induces Apoptosis in Human Endothelial Cells: Its Regulation System and Clinical Implications. Thromb Haemostasis 2003;89:875-884. [PubMed: 12719786]

15. Massa F, Marsicano G, Hermann H, Cannich A, Monory K, Cravatt BF, Ferri GL, Sibaev A, Storr M, Lutz B. The Endogenous Cannabinoid System Protects Against Colonic Inflammation. J Clin Invest 2004;113:1202-1209. [PubMed: 15085199]

16. Mallet PE, Beninger RJ. The Cannabinoid CB1 Receptor Antagonist SR141716A Attenuates the Memory Impairment Produced by $\Delta 9$-Tetrahydrocannabinol or Anandamide. Psychopharmacology 1998;140:11-19. [PubMed: 9862397]

17. Panikashvili D, Simeonidou C, Ben Shabat S, Hanus L, Breuer A, Mechoulam R, Shohami E. An Endogenous Cannabinoid (2-AG) is Neuroprotective after Brain Injury. Nature 2001;413:527-531. [PubMed: 11586361]

18. Axelrod J, Felder CC. Cannabinoid Receptors and Their Endogenous Agonist, Anandamide. Neurochem Res 1998;23:575-581. [PubMed: 9566594]

19. Di Marzo V, Bisogno T, De Petrocellis L, Melck D, Martin BR. Cannabimimetic Fatty Acid Derivatives: The Anandamide Family and Other "Endocannabinoids". Curr Med Chem 1999;6:721744. [PubMed: 10469888]

20. Martin BR, Mechoulam R, Razdan RK. Discovery and Characterization of Endogenous Cannabinoids. Life Sci 1999;65:573-595. [PubMed: 10462059] 
21. Cheer JF, Cadogan AK, Marsden CA, Fone KCF, Kendall DA. Modification of 5-HT2 Receptor Mediated Behaviour in the Rat by Oleamide and the Role of Cannabinoid Receptors. Neuropharmacology 1999;38:533-541. [PubMed: 10221757]

22. Thomas EA, Cravatt BF, Sutcliffe JG. The Endogenous Lipid Oleamide Activates Serotonin 5-HT7 Neurons in Mouse Thalamus and Hypothalamus. J Neurochem 1999;72:2370-2378. [PubMed: 10349846]

23. Boger DL, Patterson JE, Jin Q. Structural Requirements for 5-HT2A and 5-HT1A Receptor Potentiation by the Biologically Active Lipid Oleamide. Proc Natl Acad Sci US A 1998;95:41024107.

24. Lees G, Dougalis A. Differential Effects of the Sleep-Inducing Lipid Oleamide and Cannabinoids on the Induction of Long-Term Potentiation in the CA1 Neurons of the Rat Hippocampus In Vitro. Brain Res 2004;997:1-14. [PubMed: 14715144]

25. Yost CS, Hampson AJ, Leonoudakis D, Koblin DD, Bornheim LM, Gray AT. Oleamide Potentiates Benzodiazepine-Sensitive $\gamma$-Aminobutyric Acid Receptor Activity But Does Not Alter Minimum Alveolar Anesthetic Concentration. Anesth Analg 1998;86:1294-1299. [PubMed: 9620523]

26. Boger DL, Patterson JE, Guan X, Cravatt BF, Lerner RA, Gilula NB. Chemical Requirements for Inhibition of Gap Junction Communication by the Biologically Active Lipid Oleamide. Proc Natl Acad Sci US A 1998;95:4810-4815.

27. Guan X, Cravatt BF, Ehring GR, Hall JE, Boger DL, Lerner RA, Gilula NB. The Sleep-Inducing Lipid Oleamide Deconvolutes Gap Junction Communication and Calcium Wave Transmission in Glial Cells. J Cell Biol 1997;139:1785-1792. [PubMed: 9412472]

28. Huitrón-Reséndiz S, Gombart L, Cravatt BF, Henriksen SJ. Effect of Oleamide on Sleep and its Relationship to Blood Pressure, Body Temperature, and Locomotor Activity in Rats. Exp Neurol 2001;172:235-243. [PubMed: 11681856]

29. Mechoulam R, Fride E, Hanus L, Sheskin T, Bisogno T, Di Marzo V, Bayewitch M, Vogel Z. Anandamide May Mediate Sleep Induction. Nature 1997;389:25-26. [PubMed: 9288961]

30. Bracey MH, Hanson MA, Masuda KR, Stevens RC, Cravatt BF. Structural Adaptations in a Membrane Enzyme that Terminates Endocannabinoid Signaling. Science 2002;298:1793-1796. [PubMed: 12459591]

31. Cravatt BF, Giang DK, Mayfield SP, Boger DL, Lerner RA, Gilula NB. Molecular Characterization of an Enzyme that Degrades Neuromodulatory Fatty-Acid Amides. Nature 1996;384:83-87. [PubMed: 8900284]

32. Giang DK, Cravatt BF. Molecular Characterization of Human and Mouse Fatty Acid Amide Hydrolases. Proc Natl Acad Sci US A 1997;94:2238-2242.

33. Patricelli MP, Cravatt BF. Proteins Regulating the Biosynthesis and Inactivation of Neuromodulatory Fatty Acid Amides. Vit Hormones 2001;62:95-131.

34. Boger DL, Fecik RA, Patterson JE, Miyauchi H, Patricelli MP, Cravatt BF. Fatty Acid Amide Hydrolase Substrate Specificity. Bioorg Med Chem Lett 2000;10:2613-2616. [PubMed: 11128635]

35. Lang W, Qin C, Lin S, Khanolkar AD, Goutopoulos A, Fan P, Abouzid K, Meng Z, Biegel D, Makriyannis A. Substrate Specificity and Stereoselectivity of Rat Brain Microsomal Anandamide Amidohydrolase. J Med Chem 1999;42:896-902. [PubMed: 10072686]

36. Egertova M, Cravatt BF, Elphick MR. Comparative Analysis of Fatty Acid Amide Hydrolase and CB1 Cannabinoid Receptor Expression in the Mouse Brain: Evidence of a Widespread Role for Fatty Acid Amide Hydrolase in Regulation of Endocannabinoid Signaling. Neuroscience 2003;119:481496. [PubMed: 12770562]

37. Patricelli MP, Cravatt BF. Fatty Acid Amide Hydrolase Competitively Degrades Bioactive Amides and Esters Through a Nonconventional Catalytic Mechanism. Biochemistry 1999;38:14125-14130. [PubMed: 10571985]

38. Patricelli MP, Cravatt BF. Clarifying the Catalytic Roles of Conserved Residues in the Amidase Signature Family. J Biol Chem 2000;275:19177-19184. [PubMed: 10764768]

39. Patricelli MP, Lovato MA, Cravatt BF. Chemical and Mutagenic Investigations of Fatty Acid Amide Hydrolase: Evidence for a Family of Serine Hydrolases with Distinct Catalytic Properties. Biochemistry 1999;38:9804-9812. [PubMed: 10433686] 
40. Clement AB, Hawkins EG, Lichtman AH, Cravatt BF. Increased Seizure Susceptibility and Proconvulsant Activity of Anandamide in Mice Lacking Fatty Acid Amide Hydrolase. J Neurosci 2003;23:3916-3923. [PubMed: 12736361]

41. Cravatt BF, Demarest K, Patricelli MP, Bracey MH, Giang DK, Martin BR, Lichtman AH. Supersensitivity to Anandamide and Enhanced Endogenous Cannabinoid Signaling in Mice Lacking Fatty Acid Amide Hydrolase. Proc Natl Acad Sci US A 2001;98:9371-9376.

42. Cravatt BF, Saghatelian A, Hawkins EG, Clement AB, Bracey MH, Lichtman AH. Functional Disassociation of the Central and Peripheral Fatty Acid Amide Signaling Systems. Proc Natl Acad Sci US A 2004;101:10821-10826.

43. Lichtman AH, Shelton CC, Advani T, Cravatt BF. Mice Lacking Fatty Acid Amide Hydrolase Exhibit a Cannabinoid Receptor-Mediated Phenotypic Hypoalgesia. Pain 2004;109:319-327. [PubMed: 15157693]

44. Cravatt BF, Lichtman AH. Fatty Acid Amide Hydrolase: An Emerging Therapeutic Target in the Endocannabinoid System. Curr Opin Chem Biol 2003;7:469-475. [PubMed: 12941421]

45. Boger DL, Miyauchi H, Du W, Hardouin C, Fecik RA, Cheng H, Hwang I, Hedrick MP, Leung D, Acevedo O, Guimaráes CRW, Jorgensen WL, Cravatt BF. Discovery of a Potent, Selective, and Efficacious Class of Reversible $\alpha$-Ketoheterocycle Inhibitors of Fatty Acid Amide Hydrolase as Analgesics. J Med Chem 2005;48:1849-1856. [PubMed: 15771430]

46. Boger DL, Sato H, Lerner AE, Austin BJ, Patterson JE, Patricelli MP, Cravatt BF. Trifluoromethyl Ketone Inhibitors of Fatty Acid Amide Hydrolase: A Probe of Structural and Conformational Features Contributing to Inhibition. Bioorg Med Chem Lett 1999;9:265-270. [PubMed: 10021942]

47. Boger DL, Sato H, Lerner AE, Hedrick MP, Fecik RA, Miyauchi H, Wilkie GD, Austin BJ, Patricelli MP, Cravatt BF. Exceptionally Potent Inhibitors of Fatty Acid Amide Hydrolase: The Enzyme Responsible for Degradation of Endogenous Oleamide and Anandamide. Proc Natl Acad Sci US A 2000;97:5044-5049.

48. De Petrocellis L, Melck D, Ueda N, Maurelli S, Kurahashi Y, Yamamoto S, Marino G, Di Marzo V. Novel Inhibitors of Brain, Neuronal, and Basophilic Anandamide Amidohydrolase. Biochem Biophys Res Commun 1997;231:82-88. [PubMed: 9070224]

49. Deutsch DG, Omeir R, Arreaza G, Salehani D, Prestwich GD, Huang Z, Howlett A. Methyl Arachidonyl Fluorophosphonate: A Potent Irreversible Inhibitor of Anandamide Amidase. Biochem Pharmacol 1997;53:255-260. [PubMed: 9065728]

50. Deutsch DG, Lin S, Hill WAG, Morse KL, Salehani D, Arreaza G, Omeir RL, Makriyannis A. Fatty Acid Sulfonyl Fluorides Inhibit Anandamide Metabolism and Bind to the Cannabinoid Receptor. Biochem Biophys Res Commun 1997;231:217-221. [PubMed: 9070252]

51. Du W, Hardouin C, Cheng H, Hwang I, Boger DL. Heterocyclic Sulfoxide and Sulfone Inhibitors of Fatty Acid Amide Hydrolase. Bioorg Med Chem Lett 2005;15:103-106. [PubMed: 15582420]

52. Edgemond WS, Greenberg MJ, McGinley PJ, Muthians S, Campbell WB, Hillard CJ. Synthesis and Characterization of Diazomethylarachidonyl Ketone: An Irreversible Inhibitor of $\mathrm{N}$ Arachidonylethanolamine Amidohydrolase. J Pharmacol Exp Ther 1998;286:184-190. [PubMed: 9655859]

53. Fernando SR, Pertwee RG. Evidence that Methyl Arachidonyl Fluorophosphonate is an Irreversible Cannabinoid Receptor Antagonist. Br J Pharmacol 1997;121:1716-1720. [PubMed: 9283708]

54. Koutek B, Prestwich GD, Howlett AC, Chin SA, Salehani D, Akhavan N, Deutsch DG. Inhibitors of Arachidonoyl Ethanolamide Hydrolysis. J Biol Chem 1994:269.

55. Patricelli MP, Patterson JP, Boger DL, Cravatt BF. An Endogenous Sleep-Inducing Compound is a Novel Competitive Inhibitor of Fatty Acid Amide Hydrolase. Bioorg Med Chem Lett 1998;8:613618. [PubMed: 9871570]

56. Patterson JE, Ollmann IR, Cravatt BF, Boger DL, Wong CH, Lerner RA. Inhibition of Oleamide Hydrolase Catalyzed Hydrolysis of the Endogenous Sleep-Inducing Lipid cis-9-Octadecenamide. J Am Chem Soc 1996;118:5938-5945.

57. Tarzia G, Duranti A, Gatti G, Piersanti G, Tontini A, Rivara S, Lodola A, Plazzi PV, Mor M, Kathuria S, Piomelli D. Synthesis and Structure-Activity Relationships of FAAH Inhibitors: Cyclohexylcarbamic Acid Biphenyl Esters with Chemical Modulation at the Proximal Phenyl Ring. ChemMedChem 2006;1:130-139. [PubMed: 16892344] 
58. Tarzia G, Duranti A, Tontini A, Piersanti G, Mor M, Rivara S, Plazzi PV, Park C, Kathuria S, Piomelli D. Design, Synthesis, and Structure-Activity Relationships of Alkylcarbamic Acid Aryl Esters, a New Class of Fatty Acid Amide Hydrolase Inhibitors. J Med Chem 2003;46:2352-2360. [PubMed: 12773040]

59. Mor M, Rivara S, Lodola A, Plazzi PV, Tarzia G, Duranti A, Tontini A, Piersanti G, Kathuria S, Piomelli D. Cyclohexylcarbamic Acid 3'- or 4'-Substituted Biphenyl-3-yl Esters as Fatty Acid Amide Hydrolase Inhibitors: Synthesis, Quantitative Structure-Activity Relationships, and Molecular Modeling Studies. J Med Chem 2004;47:4998-5008. [PubMed: 15456244]

60. Muccioli GG, Fazio N, Scriba GKE, Poppitz W, Cannata F, Poupaert JH, Wouters J, Lambert DM. Substituted 2-Thioxoimidazolidin-4-ones and Imidazolidine-2,4-diones as Fatty Acid Amide Hydrolase Inhibitors Templates. J Med Chem 2006;49:417-425. [PubMed: 16392827]

61. Romero FA, Hwang I, Boger DL. Delineation of a Fundamental $\alpha$-Ketoheterocycle Substituent Effect For Use in the Design of Enzyme Inhibitors. J Am Chem Soc 2006;128:14004-14005. [PubMed: 17061864]

62. Leung D, Du W, Hardouin C, Cheng H, Hwang I, Cravatt BF, Boger DL. Discovery of an Exceptionally Potent and Selective Class of Fatty Acid Amide Hydrolase Inhibitors Enlisting Proteome-Wide Selectivity Screening: Concurrent Optimization of Enzyme Inhibitor Potency and Selectivity. Bioorg Med Chem Lett 2005;15:1423-1428. [PubMed: 15713400]

63. Hohmann AG, Suplita RL, Bolton NM, Neeley MH, Fegley D, Mangieri R, Krey J, Walker JM, Holmes PV, Crystal JD, Duranti A, Tontini A, Mor M, Tarzia G, Piomelli D. An Endocannabinoid Mechanism for Stress-Induced Analgesia. Nature 2005;435:1108-1112. [PubMed: 15973410]

64. Alexander JP, Cravatt BF. The Putative Endocannabinoid Transport Blocker LY2183240 Is a Potent Inhibitor of FAAH and Several Other Brain Serine Hydrolases. J Am Chem Soc 2006;128:9699_ 9704. [PubMed: 16866524]

65. Alexander JP, Cravatt BF. Mechanism of Carbamate Inactivation of FAAH: Implications for the Design of Covalent Inhibitors and In Vivo Functional Probes for Enzymes. Chem Biol 2005;12:1179_ 1187. [PubMed: 16298297]

66. Lichtman AH, Leung D, Shelton CC, Saghatelian A, Hardouin C, Boger DL, Cravatt BF. Reversible Inhibitors of Fatty Acid Amide Hydrolase that Promote Analgesia: Evidence for an Unprecedented Combination of Potency and Selectivity. J Pharmacol Exp Ther 2004;311:441-448. [PubMed: 15229230]

67. Boger DL, Miyauchi H, Hedrick MP. $\alpha$-Keto Heterocycle Inhibitors of Fatty Acid Amide Hydrolase: Carbonyl Group Modification and $\alpha$-Substitution. Bioorg Med Chem Lett 2001;11:1517-1520. [PubMed: 11412972]

68. Chang L, Luo L, Palmer JA, Sutton S, Wilson SJ, Barbier AJ, Breitenbucher JG, Chaplan SR, Webb M. Inhibition of Fatty Acid Amide Hydrolase Produces Analgesia by Multiple Mechanisms. Br J Pharmacol 2006;148:102-113. [PubMed: 16501580]

69. Leung D, Hardouin C, Boger DL, Cravatt BF. Discovering Potent and Selective Reversible Inhibitors of Enzymes in Complex Proteomes. Nature Biotech 2003;21:687-691.

70. Vedejs E, Monahan SD. Metalation of Oxazole-Borane Complexes: A Practical Solution to the Problem of Electrocyclic Ring Opening of 2-Lithiooxazoles. J Org Chem 1996;61:5192-5193.

71. Hari Y, Obika S, Sakaki M, Morio K, Yamagata Y, Imanishi T. Effective Synthesis of C-Nucleosides with 2',4'-BNA Modification. Tetrahedron 2002;58:3051-3063.

72. Farina V, Krishnamurthy V, Scott WJ. The Stille Reaction. Org React 1997;50:1-652.

73. Dess DB, Martin JC. A Useful 12-I-5 Triacetoxyperiodinane (the Dess-Martin periodinane) for the Selective Oxidation of Primary or Secondary Alcohols and a Variety of Related 12-I-5 Species. J Am Chem Soc 1991;113:7277-7287.

74. Chen Q-Y, Wu S-W. Methyl Fluorosulphonyldifluoroacetate; A New Trifluoromethylating Agent. J Chem Soc, Chem Commun 1989:705-706.

75. Qing F-L, Fan J, Sun H-B, Yue X-J. First Synthesis of ortho-Trifluoromethylated Aryl Triflates. J Chem Soc, Perkin Trans 1997;1:3053-3057.

76. Patricelli MP, Lashuel HA, Giang DK, Kelly JW, Cravatt BF. Comparative Characterization of a Wild Type and Transmembrane Domain-Deleted Fatty Acid Amide Hydrolase: Identification of the 
Transmembrane Domain as a Site for Oligomerization. Biochemistry 1998;37:15177-15187. [PubMed: 9790682]

77. Guimaráes CRW, Boger DL, Jorgensen WL. Elucidation of Fatty Acid Amide Hydrolase Inhibition by Potent $\alpha$-Ketoheterocycle Derivatives from Monte Carlo Simulations. J Am Chem Soc 2005;127:17377-17384. [PubMed: 16332087]

78. Edwards PD, Zottola MA, Davis M, Williams CM, Tuthill PA. Peptidyl $\alpha$-Ketoheterocyclic Inhibitors of Human Neutrophil Elastase. 3. In Vitro Potency and in Vivo Potency of a Series of Peptidyl $\alpha-$ Ketobenzoxazoles. J Med Chem 1995;38:3972-3982. [PubMed: 7562931]

79. Edwards PD, Zottola MA, Davis M, Williams J, Tuthill PA. Peptidyl $\alpha$-Ketoheterocyclic Inhibitors of Human Neutrophil Elastase. 2. Effect of Varying the Heterocyclic Ring on in Vitro Potency. J Med Chem 1995;38:76-85. [PubMed: 7837243]

80. Costanzo MJ, Almond HR, Hecker LR, Schott MR, Yabut SC, Zhang HC, Andrade-Gordon P, Corcoran TW, Giardino EC, Kauffman JA, Lewis JM, de Garavilla L, Haertlein BJ, Maryanoff BE. In-Depth Study of Tripeptide-Based $\alpha$-Ketoheterocycles as Inhibitors of Thrombin. Effective Utilization of the S1' Subsite and Its Implications to Structure-Based Drug Design. J Med Chem 2005;48:1984-2008. [PubMed: 15771442] 
<smiles>CCCCC/C=C\C/C=C\C/C=C/C/C=C/CCCC(=O)NCCO</smiles><smiles>CCCCCCCC/C=C/CCCCCCCC(N)=O</smiles>

Oleamide (1b)

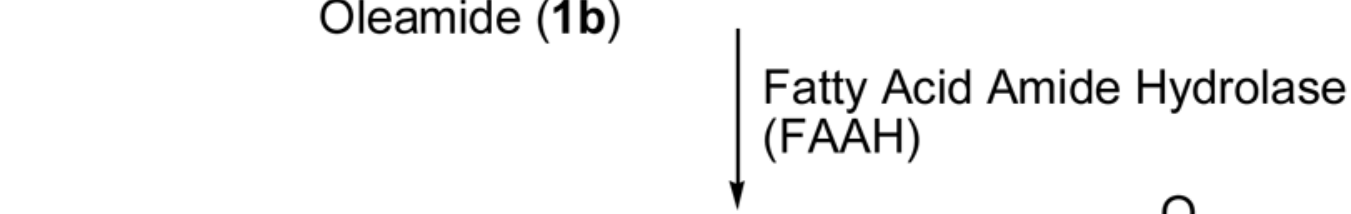<smiles>CCCCC/C=C\C/C=C\C/C=C\C/C=C/CCCC(=O)O</smiles><smiles>CCCCCCCC/C=C/CCCCCCCC(=O)O</smiles>

Oleic Acid (1d)

Figure 1.

Substrates of fatty acid amide hydrolase (FAAH). 
<smiles>CCCCCC[C@H](C)OC(=O)CC(=O)CBr</smiles><smiles>O=C(CCCCCCCc1ccccc1)C(F)(F)F</smiles><smiles>CCCCC/C=C\C/C=C\CCCCP(=O)(F)OC</smiles>

2c, $I C_{50}=0.0025 \mu \mathrm{M}$<smiles>NC(=O)c1cccc(-c2cccc(OC(=O)NC3CCCCC3)c2)c1</smiles>

\section{2d (URB-597)}

$\mathrm{IC}_{50}=0.0046 \mu \mathrm{M}$<smiles>O=C(CCCCCCc1ccccc1)c1nc2ncccc2o1</smiles>

2e (OL-92)

$K_{\mathrm{i}}=0.00028 \mu \mathrm{M}$

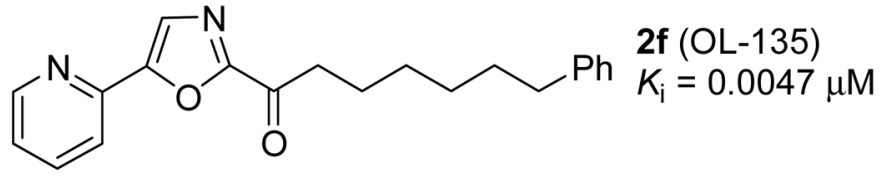

Figure 2.

Examples of FAAH inhibitors. 
<smiles>C=C(CCCCCCc1ccccc1)c1ncc(P)o1</smiles>

O

\begin{tabular}{cll} 
compd & \multicolumn{1}{c}{$\mathrm{R}$} & $K_{\mathrm{i}}, \mu \mathrm{M}$ \\
\hline $\mathbf{2 f}$ & 2-pyridyl & 0.0047 \\
$\mathbf{2 g}$ & 2-furyl & 0.012 \\
$\mathbf{2 h}$ & 2-thienyl & 0.055 \\
$\mathbf{2 i}$ & phenyl & 0.08
\end{tabular}

Figure 3.

$\alpha$-Keto oxazole inhibitors of FAAH. 
<smiles>[R][R](=O)O[Y4]=[R]</smiles>

\begin{tabular}{|c|c|c|c|c|c|}
\hline \multirow{2}{*}{$\frac{\mathrm{R}}{\mathrm{NO}_{2}}$} & \multicolumn{3}{|r|}{$\begin{array}{c}K_{\mathrm{i}}(\mu \mathrm{M}) \\
\text { 3-position }\end{array}$} & \multicolumn{2}{|c|}{ 4-position } \\
\hline & 0.13 & $(12 a)$ & $0.028(13 a)$ & 0.05 & $(14 a)$ \\
\hline $\mathrm{NH}_{2}$ & 0.75 & $(12 b)$ & 0.019 (13b) & 0.09 & $(14 b)$ \\
\hline $\mathrm{CO}_{2} \mathrm{CH}_{3}$ & 0.06 & $(12 c)$ & $0.012(13 c)$ & 0.04 & $(14 c)$ \\
\hline $\mathrm{CO}_{2} \mathrm{H}$ & 6.0 & $(12 d)$ & $0.005(13 d)$ & 0.06 & $(14 d)$ \\
\hline $\mathrm{F}$ & 0.11 & $(12 e)$ & $0.05 \quad(13 e)$ & 0.062 & $(14 e)$ \\
\hline $\mathrm{OCH}_{3}$ & 0.4 & $(12 f)$ & $0.04 \quad(13 f)$ & 0.1 & $(14 f)$ \\
\hline $\mathrm{OH}$ & 0.17 & $(12 g)$ & $0.05 \quad(13 g)$ & 0.14 & $(14 g)$ \\
\hline $\mathrm{SO}_{2} \mathrm{NH}_{2}$ & 1.5 & $(12 h)$ & 0.002 (13h) & 0.01 & (14h) \\
\hline $\mathrm{CONH}_{2}$ & 0.3 & $(12 i)$ & $0.006(13 i)$ & 0.01 & $(14 i)$ \\
\hline $\mathrm{COCF}_{3}$ & 5.0 & $(12 \mathbf{j})$ & $0.016(\mathbf{1 3} \mathbf{j})$ & 0.065 & $(14 j)$ \\
\hline $\mathrm{CN}$ & 0.13 & $(12 k)$ & 0.015 (13k) & 0.04 & $(14 k)$ \\
\hline
\end{tabular}

Figure 4.

Effect of substitution on the benzene ring. 


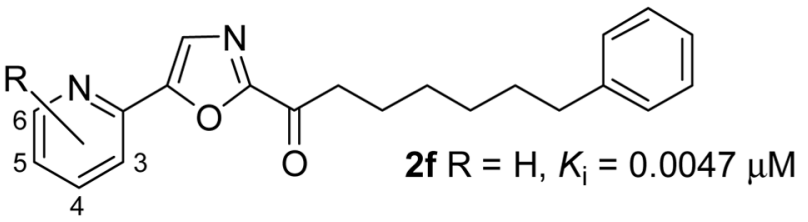

\begin{tabular}{|c|c|c|c|c|c|}
\hline compd & $\mathrm{R}$ & $K_{\mathrm{i}}, \mu \mathrm{M}$ & compd & $\mathrm{R}$ & $K_{\mathrm{i}}, \mu \mathrm{M}$ \\
\hline $15 a$ & $3-\mathrm{CH}_{3}$ & 0.015 & $15 k$ & $3-\mathrm{CO}_{2} \mathrm{CH}_{3}$ & 0.13 \\
\hline $15 b$ & $4-\mathrm{CH}_{3}$ & 0.0006 & $15 I$ & $4-\mathrm{CO}_{2} \mathrm{CH}_{3}$ & 0.0013 \\
\hline $15 c$ & $5-\mathrm{CH}_{3}$ & 0.0028 & $15 \mathrm{~m}$ & $5-\mathrm{CO}_{2} \mathrm{CH}_{3}$ & 0.0035 \\
\hline $15 d$ & $6-\mathrm{CH}_{3}$ & 0.0033 & $15 n$ & $6-\mathrm{CO}_{2} \mathrm{CH}_{3}$ & 0.008 \\
\hline $15 e$ & $4-\mathrm{OCH}_{3}$ & 0.0008 & 150 & $3-\mathrm{CO}_{2} \mathrm{H}$ & $>0.05$ \\
\hline $15 f$ & $4-\mathrm{CN}$ & 0.0011 & $15 p$ & $4-\mathrm{CO}_{2} \mathrm{H}$ & 0.05 \\
\hline $15 \mathrm{~g}$ & $4-\mathrm{CF}_{3}$ & 0.0035 & $15 q$ & $5-\mathrm{CO}_{2} \mathrm{H}$ & 0.007 \\
\hline $15 \mathrm{~h}$ & $4-\mathrm{NO}_{2}$ & 0.0032 & $15 r$ & $6-\mathrm{CO}_{2} \mathrm{H}$ & 0.02 \\
\hline $15 i$ & $4-\mathrm{NH}_{2}$ & 0.025 & $15 s$ & $5-\mathrm{CONH}_{2}$ & 0.0012 \\
\hline $15 j$ & $4-\mathrm{F}$ & 0.002 & $15 t$ & $6-\mathrm{CONH}_{2}$ & 0.001 \\
\hline
\end{tabular}<smiles>[R][R4]Oc1ccc(CCCCCC(=O)c2ncc(-c3ccc([R])o3)o2)cc1</smiles>

\begin{tabular}{cccccc} 
compd & $\mathrm{R}$ & $K_{\mathrm{i}}, \mu \mathrm{M}$ & compd & $\mathrm{R}$ & $K_{\mathrm{i}}, \mu \mathrm{M}$ \\
\hline 16a & $-\mathrm{CO}_{2} \mathrm{CH}_{3}$ & 0.0055 & 16b & $-\mathrm{CO}_{2} \mathrm{H}$ & 0.015
\end{tabular}<smiles>[R]CCCCCC(=O)c1ncc(-c2ccc([R])s2)o1</smiles>

Figure 5.

Effect of substitution on a pyridine, furan and thiophene ring. 
<smiles>[R]c1cnc(C(=O)CCCCCCc2ccccc2)o1</smiles>

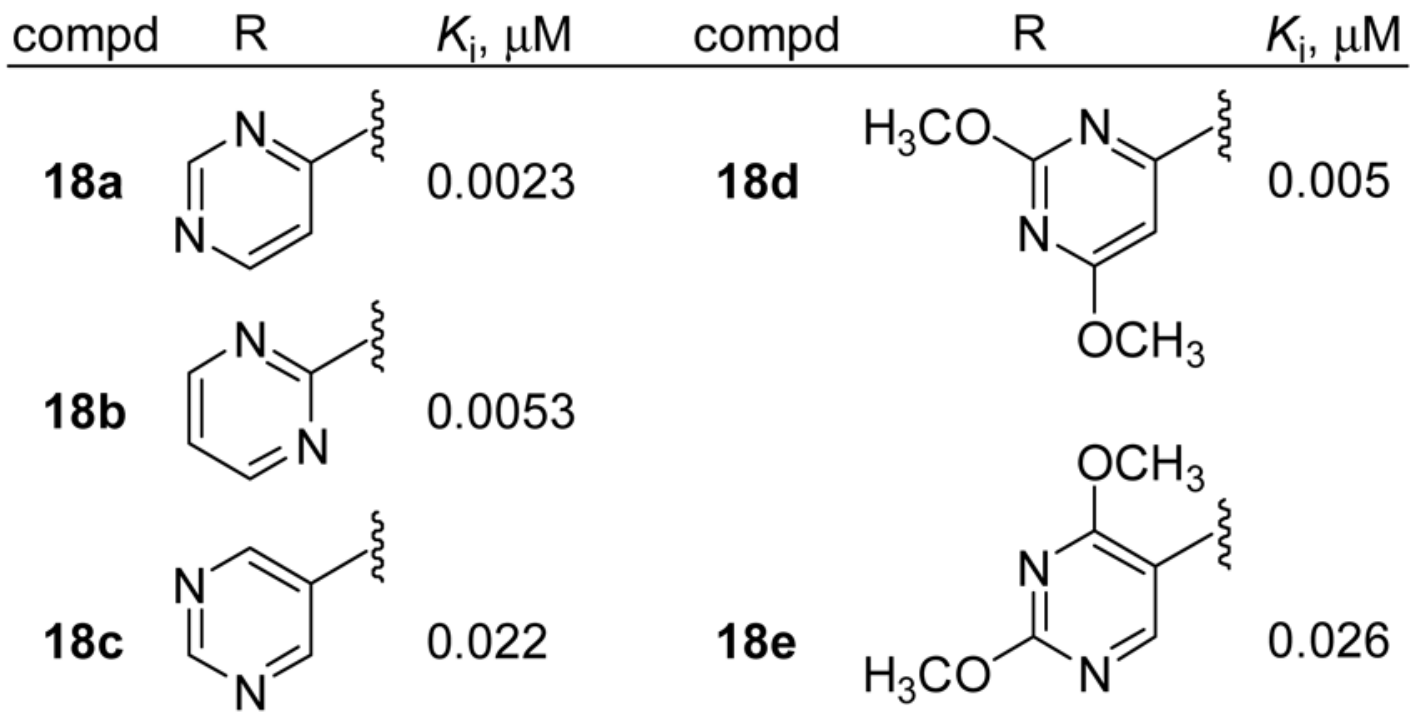<smiles>CC(C)(C)c1ncc(-c2cnc(C(=O)c3ncc(-c4nnn[nH]4)o3)o2)o1</smiles>

Figure 6.

Effect of additional aryl groups. Compounds $18 \mathbf{a}-\mathbf{c}$ are from a previous study. ${ }^{45}$ See Supporting Information for a more extensive table which includes previous 5-heterocyclic substituents. 
<smiles>[R]c1cnc(C(=O)CCCCCCc2ccccc2)o1</smiles>

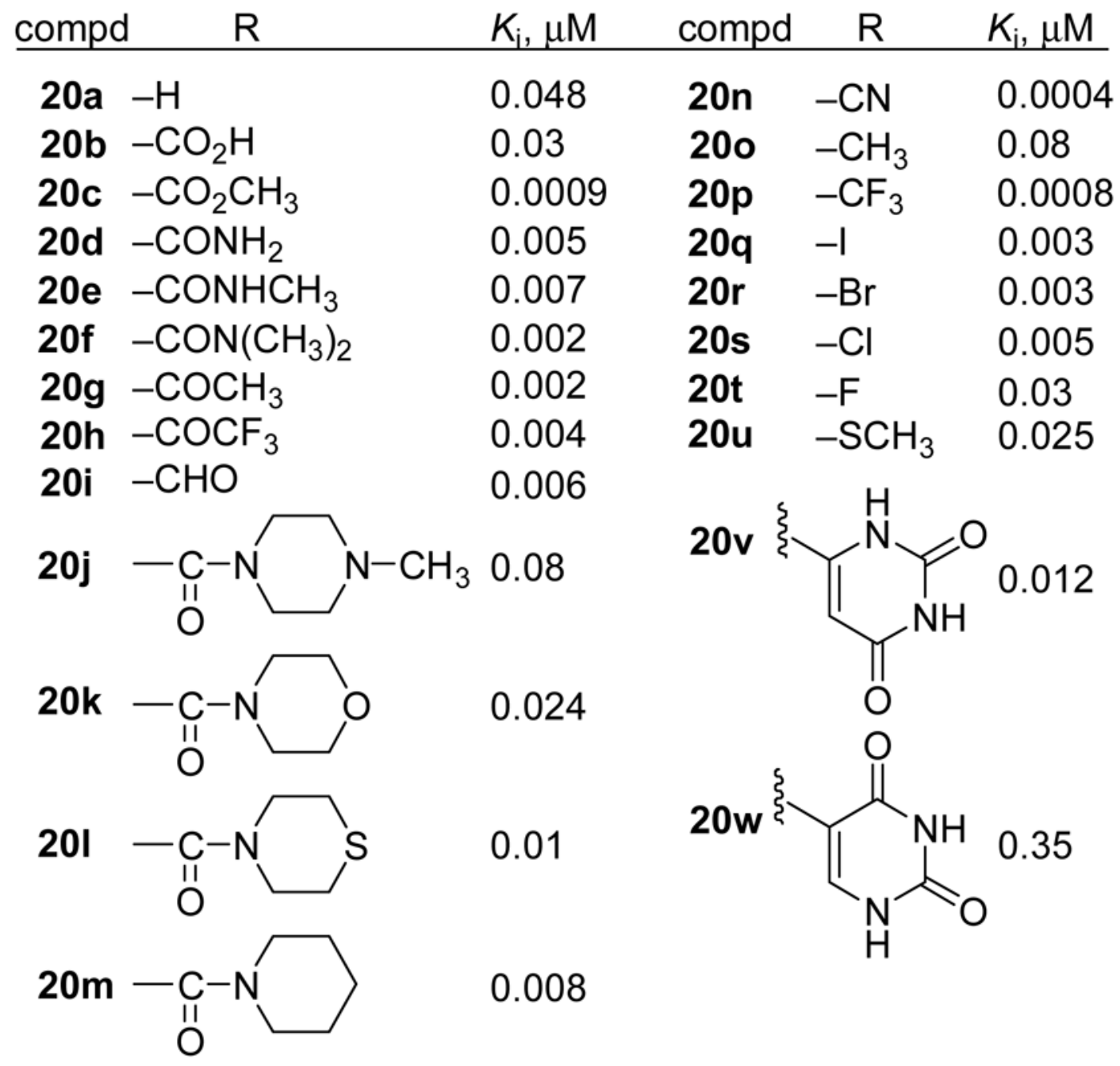

Figure 7.

Effect of non-aromatic substituents. 


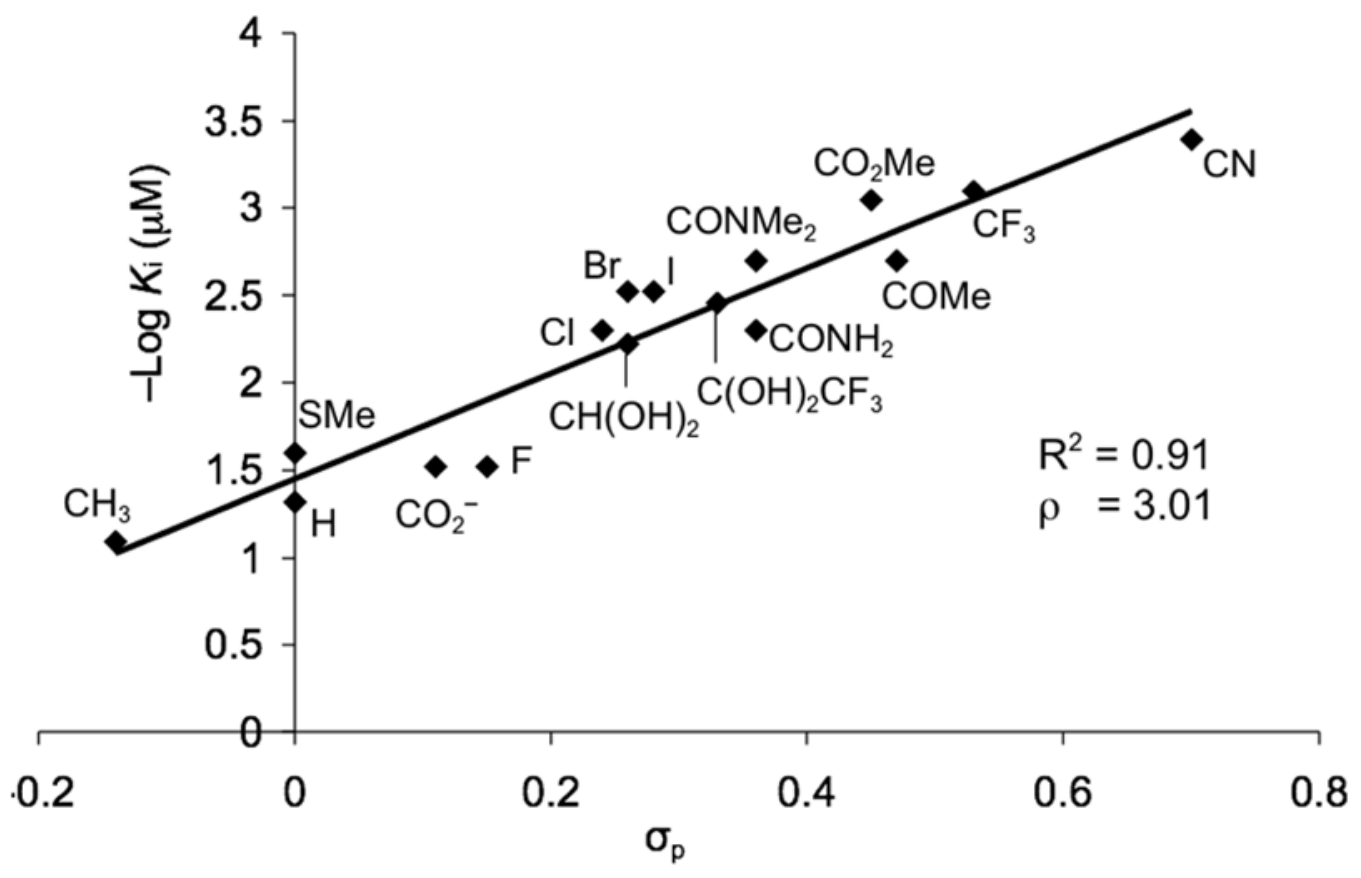

Figure 8.

$-\log K_{\mathrm{i}}(\mu \mathrm{M})$ versus $\boldsymbol{\sigma}_{\mathrm{p}}$. 


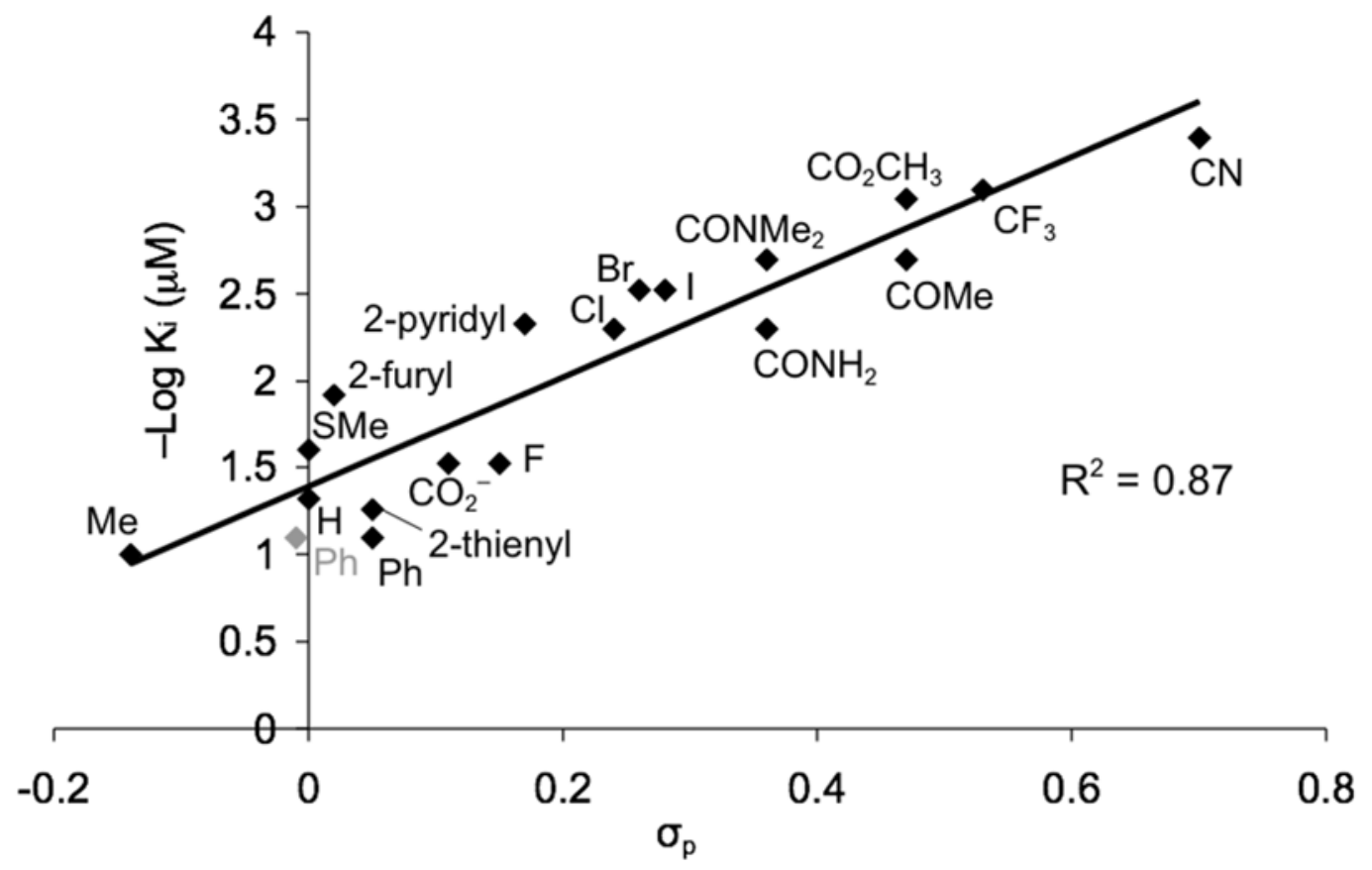

Figure 9.

$-\log K_{\mathrm{i}}(\mu \mathrm{M})$ versus $\boldsymbol{\sigma}_{\mathrm{p}}$. 
<smiles>[R]c1cnc([C@@H](O)CCCCCCc2ccccc2)o1</smiles>

\begin{tabular}{|c|c|c|c|c|c|}
\hline compd & $\mathrm{R}$ & $K_{\mathrm{i}}, \mu \mathrm{M}$ & compd & $\mathrm{R}$ & $K_{\mathrm{i}}, \mu \mathrm{M}$ \\
\hline $21 a$ & $-\mathrm{CN}$ & 4.2 & & & \\
\hline 21b & $-\mathrm{CF}_{3}$ & 2.3 & $21 f$ & & 25 \\
\hline 21c & $-\mathrm{CO}_{2} \mathrm{CH}_{3}$ & 2.0 & & & \\
\hline 21d & $-\mathrm{CONH}_{2}$ & 25 & & & \\
\hline $21 e$ & $-\mathrm{CON}\left(\mathrm{CH}_{3}\right)_{2}$ & 16 & & O & \\
\hline
\end{tabular}<smiles>[R][R]1cccc(-c2cnc([C@@H](O)CCCCCCc3ccccc3)o2)n1</smiles>

\begin{tabular}{cccccc} 
compd & $\mathrm{R}$ & $K_{\mathrm{i}}, \mu \mathrm{M}$ & compd & $\mathrm{R}$ & $K_{\mathrm{i}}, \mu \mathrm{M}$ \\
\hline $\mathbf{2 1 g}$ & $6-\mathrm{CO}_{2} \mathrm{CH}_{3}$ & 2.3 & $\mathbf{2 1 j}$ & $5-\mathrm{CO}_{2} \mathrm{H}$ & 45 \\
$\mathbf{2 1 h}$ & $5-\mathrm{CO}_{2} \mathrm{CH}_{3}$ & $>10$ & $\mathbf{2 1 k}$ & $6-\mathrm{CONH}_{2}$ & 2.1 \\
$\mathbf{2 1 \mathrm { i }}$ & $6-\mathrm{CO}_{2} \mathrm{H}$ & $>10$ & $\mathbf{2 1 \mathbf { l }}$ & $5-\mathrm{CONH}_{2}$ & 3.0
\end{tabular}

Figure 10.

The effect of removing the electrophilic carbonyl. 


\begin{tabular}{ccc} 
compd & $K_{\mathrm{i}}, \mu \mathrm{M}$ (human) & $K_{\mathrm{i}}, \mu \mathrm{M}$ (rat) \\
\hline $\mathbf{1 5 q}$ & 0.008 & 0.007 \\
$\mathbf{1 5 r}$ & 0.026 & 0.02 \\
$\mathbf{2 0 b}$ & 0.032 & 0.03 \\
$\mathbf{2 0 n}$ & 0.001 & 0.0004
\end{tabular}

Figure 11.

Inhibition of Recombinant Human Fatty Acid Amide Hydrolase. 


\begin{tabular}{|c|c|c|c|c|}
\hline compd & $K_{\mathrm{i}}, \mu \mathrm{M}$ & $\mathrm{FAAH}$ & KIAA1363 & $\mathrm{TGH}$ \\
\hline $2 f$ & 0.0047 & 0.002 & $>100(>50000)$ & $0.6(300)$ \\
\hline $13 d$ & 0.005 & 1.4 & $>100(>70)$ & $>100(>70)$ \\
\hline $13 \mathrm{~h}$ & 0.002 & 0.4 & $>100(>200)$ & $0.2(0.5)$ \\
\hline $13 i$ & 0.006 & 2.7 & $>100(>40)$ & $>100(40)$ \\
\hline $15 b$ & 0.0006 & 0.001 & $>100(>100000)$ & $2(2000)$ \\
\hline $15 e$ & 0.0008 & 0.0017 & $>100(>59000)$ & $0.5(300)$ \\
\hline $15 f$ & 0.0011 & 0.0008 & $>100(>125000)$ & $0.4(500)$ \\
\hline $15 g$ & 0.0035 & 0.0015 & $>100(>67000)$ & $2(1300)$ \\
\hline $15 \mathrm{~h}$ & 0.0032 & 0.0016 & $>100(>63000)$ & $0.2(125)$ \\
\hline $15 i$ & 0.025 & 0.34 & $>100(>300)$ & $34(100)$ \\
\hline $15 j$ & 0.002 & 0.0025 & $>100(>40000)$ & $0.6(240)$ \\
\hline $15 I$ & 0.0013 & 0.0006 & $>100(>170000)$ & $0.9(2000)$ \\
\hline $15 q$ & 0.007 & 0.05 & $>100(>2000)$ & $3(60)$ \\
\hline $15 r$ & 0.02 & 0.1 & $>100(>1000)$ & $>100(>1000)$ \\
\hline $16 b$ & 0.015 & 0.85 & $>100(>120)$ & $>100(>120)$ \\
\hline $18 d$ & 0.005 & 0.4 & $>100(>250)$ & $0.07(0.2)$ \\
\hline $18 \mathrm{e}$ & 0.026 & 9 & $>100(>11)$ & $3(0.3)$ \\
\hline $20 a$ & 0.048 & 2.5 & $19(8)$ & $0.02(0.008)$ \\
\hline $20 b$ & 0.030 & 0.97 & $>100(>100)$ & $>100(>100)$ \\
\hline $20 c$ & 0.0009 & 0.03 & $>100(>3300)$ & $0.3(10)$ \\
\hline $20 d$ & 0.0045 & 0.35 & $>100(>300)$ & $7(20)$ \\
\hline $20 m$ & 0.008 & 0.45 & $>100(>200)$ & $8(20)$ \\
\hline $20 n$ & 0.0004 & 0.0065 & $>100(>15400)$ & $0.02(3)$ \\
\hline $20 p$ & 0.0008 & 0.077 & $>100(>1300)$ & $0.2(3)$ \\
\hline $20 r$ & 0.003 & 0.19 & $13(70)$ & $0.1(0.5)$ \\
\hline $20 v$ & 0.012 & 0.005 & $>100(>20000)$ & $30(6200)$ \\
\hline $20 w$ & 0.35 & $\mathrm{t}-\mathrm{Bu}$ & $>100(>150)$ & $30(40)$ \\
\hline
\end{tabular}

Figure 12.

Selectivity screening; $\mathrm{IC}_{50}, \mu \mathrm{M}$ (selectivity). 


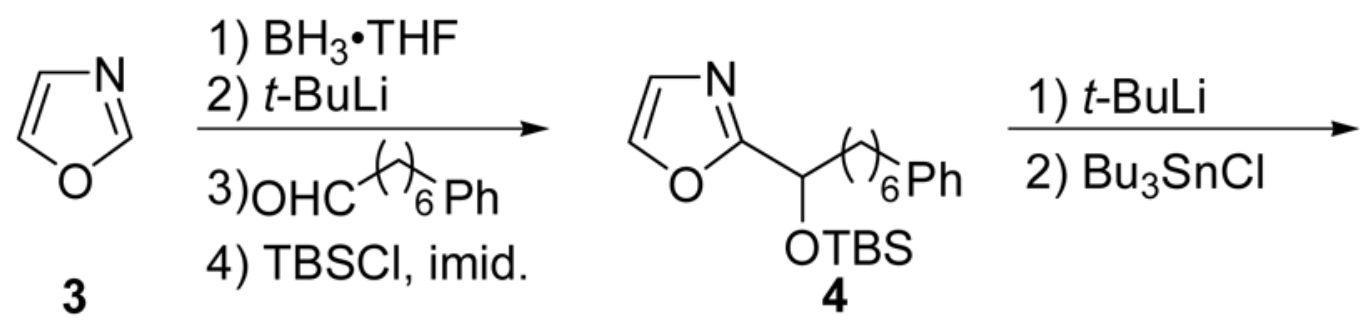

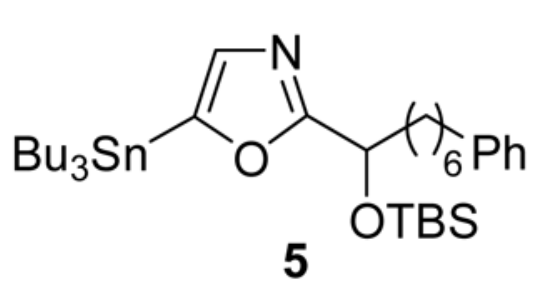

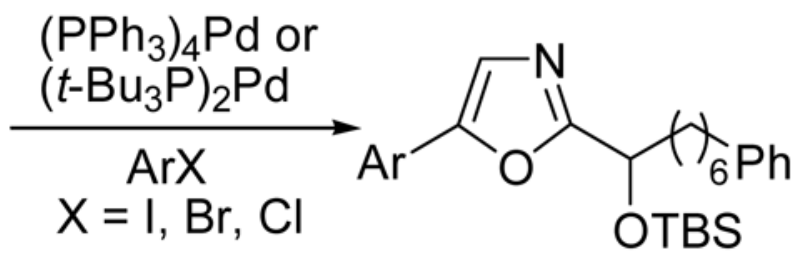

6-8, $\mathrm{Ar}=\mathrm{RC}_{6} \mathrm{H}_{4}$

9, $\mathrm{Ar}=\mathrm{RC}_{6} \mathrm{H}_{3} \mathrm{~N}$

10, $\mathrm{Ar}=\mathrm{RC}_{4} \mathrm{H}_{2} \mathrm{O}$

11, $\mathrm{Ar}=\mathrm{RC}_{4} \mathrm{H}_{2} \mathrm{~S}$<smiles>O=C(CCCCCCc1ccccc1)c1ncc(Br)o1</smiles>

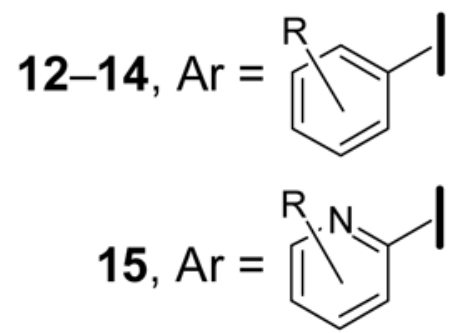<smiles>[R]c1ccc(I)o1</smiles>

Scheme 1. 


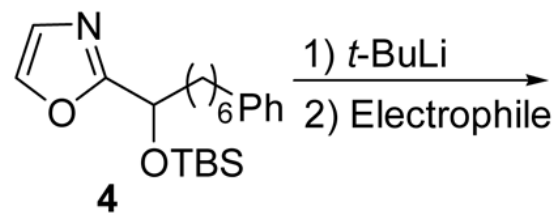
$\mathrm{R}^{1}=\mathrm{CO}_{2} \mathrm{H}, \mathrm{CF}_{3} \mathrm{CO}, \mathrm{CH}_{3} \mathrm{CO}, \mathrm{HCO}$, $\mathrm{I}, \mathrm{Br}, \mathrm{Cl}, \mathrm{F}, \mathrm{Me}, \mathrm{SCH}_{3}$

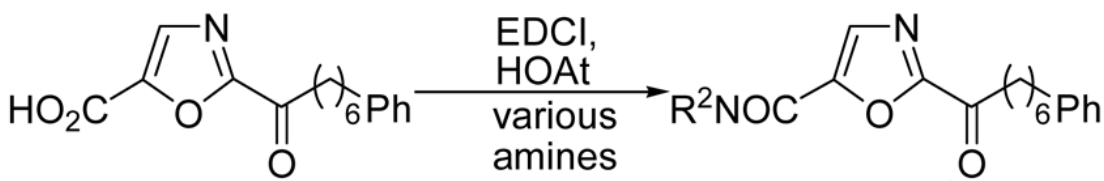
20b 20e, 20f, 20j-m

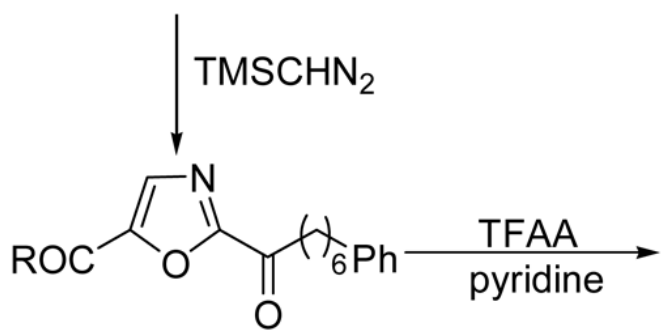<smiles>[R]c1cnc(C(=O)C(=O)c2ccccc2)o1</smiles><smiles>COC(=O)C(=O)OC(N)=O</smiles><smiles>[R]Cc1[nH]nnc1[R6]#N</smiles>

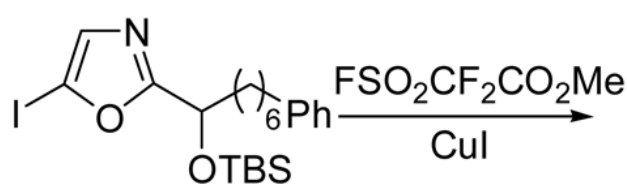
$19 q$<smiles>FC(F)(F)c1cnc(C([GeH2])[PbH2]c2ccccc2)o1</smiles>
$19 p$

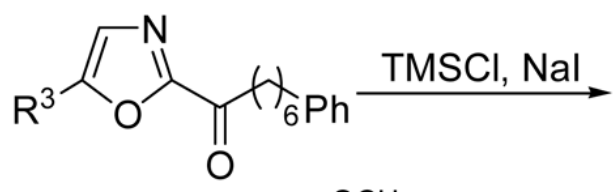<smiles>[R4]c1cnc(C(=O)[AsH2]c2ccccc2)o1</smiles>

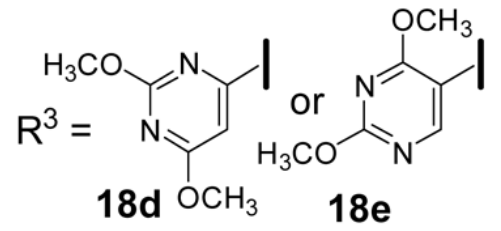<smiles>[R]ON1CNC(=O)C(CI)=CC1=O</smiles>

Scheme 2. 